\title{
Supporting Students With Health Needs in Schools: An Overview of Selected Health Conditions
}

\author{
Linda Garrison-Kane \\ Missouri State University \\ Paris A. DePaepe \\ Missouri State University \\ Jane E. Doelling \\ Missouri State University
}

Follow this and additional works at: https://bearworks. missouristate.edu/articles-coe

\section{Recommended Citation}

DePaepe, Paris, Linda Garrison-Kane, and Jane Doelling. "Supporting students with health needs in schools: An overview of selected health conditions." Annual Conference of the Eastern Educational Research Association 35, no. 1 (2002): 1-+.

This article or document was made available through BearWorks, the institutional repository of Missouri State University. The work contained in it may be protected by copyright and require permission of the copyright holder for reuse or redistribution.

For more information, please contact BearWorks@library.missouristate.edu. 


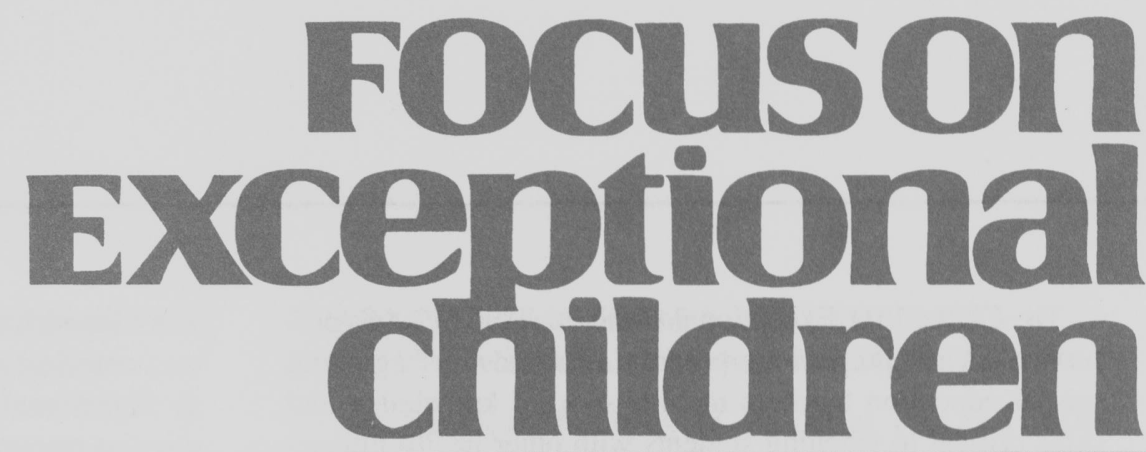

\title{
Supporting Students With Health Needs in Schools: An Overview of Selected Health Conditions
}

\author{
Paris DePaepe, Linda Garrison-Kane, and Jane Doelling
}

According to the 23rd Annual Report to Congress (U.S. Department of Education, 2001) on the Implementation of Individuals with Disabilities Education Act, 254,110 students were classified as eligible under the Other Health Impairment category in 1999-2000. This number represents a 351\% increase from the total number of students eligible in that category during 1990-1991. The increase in percentage of students who have health problems that adversely affect their educational performance has been greater than any other eligibility category since 1990 . During $1999-2000,26 \%$ of children in early childhood special education (ECSE) received medication and $16 \%$ reportedly used medical equipment such as nebulizers and breathing monitors.

Because more children are found eligible for special education services as a result of having an "other health impairment" special education professionals have voiced concern about the inadequate training that preservice teachers receive in this area (Heller, Fredrick, Dykes, Best \& Cohen, 1999). This concern is further exacerbated by the increasing trend toward a noncategorical or cross-categorical focus within special education teacher preparation programs in the United States. Teachers who will instruct students with mild to moderate disabilities need a common core of knowledge and skill competencies (Simpson, Whelan, \& Zabel, 1993). These students will have mental retardation (MR), learning disabilities (LD), or emotional disturbances (ED) of a mild to moderate nature. Heller (1997) asserted that teachers also need appropriate preservice training to serve students diagnosed with a variety of physical and health impairments and warned that these students are at significant risk when educators are not adequately prepared to meet their specialized health care needs.

Paris DePaepe and Linda Garrison-Kane are associate professors and Jane Doelling a professor in the School of Teacher Education, Southwest Missouri State University.

The authors would like to acknowledge Jennifer Neumann for her assistance with manuscript preparation. 
The Council for Exceptional Children (CEC) (2000) preservice teacher preparation program standards for beginning special education teachers include specific knowledge and skills critical to teaching students with other health impairments. In part, special educators need to acquire knowledge and skills related to students with health disabilities. Training should emphasize:

- Knowledge regarding health conditions, and their effect on development and student behavior; etiology of and medical aspects of the conditions

- Related psychological and emotional characteristics

- Methods for screening, referral, and placement; implementation of appropriate assistive technology and other accommodations

- Lesson plan adaptation for students with specialized health conditions; use of outside resources for programming

- Collaboration with related services personnel to maximize academic engaged time, as well as identification of specialized service and organizations

\section{Focuson
Exceptional
children}

ISSN 0015-511X

FOCUS ON EXCEPTIONAL CHILDREN (USPS 203-360) is published monthly except June, July, and August as a service to teachers, special educators, curriculum specialists, administrators, and those concerned with the special education of exceptional children. This publication is annotated and indexed by the ERIC Clearinghouse on Handicapped and Gifted children for publication in the monthly Current Index to Journals in Education (CIJE) and the quarterly index, Exceptional Children Education Resources (ECER). The full text of Focus on Exceptional Children is also available in the electronic versions of the Education Index. It is also available in microfilm from Xerox University Microfilms, Ann Arbor, MI. Subscription rates: Individual, \$36 per year; institutions, $\$ 48$ per year. Copyright (C) 2002, Love Publishing Company. All rights reserved. Reproduction in whole or part without written permission is prohibited. Printed in the United States of America. Periodical postage is paid at Denver, Colorado. POSTMASTER: Send address changes to:

$$
\begin{gathered}
\text { Love Publishing Company } \\
\text { Executive and Editorial Office } \\
\text { P.O. Box } 22353 \\
\text { Denver, Colorado } 80222 \\
\text { Telephone (303) 221-7333 }
\end{gathered}
$$

Karen Harris

University of Maryland
Thomas Skrtic University of Kansas

James Shriner

University of Illinois

Erica J. Lawrence Editor
Stanley F. Love

Publisher
- Identification of roles and responsibilities of school medical and related service personnel, as well as professional organizations and networks that may serve as resources.

In addition, CEC noted that beginning special education teachers should have knowledge of infectious diseases and their transmission routes, and must follow confidentiality policies related to both academic and medical records.

Special education and general education teachers must have the background knowledge and skills necessary to plan for and provide appropriate educational services, schoolrelated health services, and accommodations for students diagnosed with a wide variety of health conditions. Heller et al. (1999) assessed the perceived competency of general education and special education teachers, who taught students with physical and health impairments, with respect to their preparation for working effectively with that population. Among special educators who were certified to teach students with physical and health disabilities, $40 \%$ reported that they were not well trained in 11 of 23 critical competencies. The authors cautioned that generic cross-categorical special education teacher training programs and certifications will lead to fewer teachers with specialties in physical and health disabilities.

Providing education and related services that include school health care for students with disabilities has brought the field to an educational and medical crossroad (Caldwell \& Sirvis, 1991; Johnson, Lubker, \& Fowler, 1988; Thies, 1999). This issue is further magnified by the conflicting judicial rulings on what constitutes a related health service or a physician-provided service for students with health impairments (Katsiyannis \& Yell, 2000). Currently, individualized education program (IEP) teams must differentiate what service augments and supports this student population versus what constitutes a supplementary aid and service that educates the student in a general education environment (Etscheidt \& Bartlett, 1999). School personnel require specialized knowledge about each student's educational and health care needs in order to adequately address them (Caldwell \& Sirvis). Johnson et al. asserted that schools are unprepared to accomplish this goal.

The professional literature provides teachers with current and valid information regarding the health conditions of students. With the reauthorization of the Individuals with Disabilities Education Act (1997), attention deficit disorder (ADD) and attention deficit hyperactivity disorder (ADHD) are now specifically included within the Other Health Impairment category; however, readers are directed to Reid (1999) for a comprehensive discussion of educational methods and effective classroom-management techniques for students with ADHD. In addition, in an earlier issue of 
Focus on Exceptional Children, Tyler and Colson (1994) provided a comprehensive review of common pediatric conditions (i.e., Down syndrome, Turner syndrome, fragile $\mathrm{X}$, $\mathrm{ADHD}$, cerebral palsy, leukemia, neurofibromatosis, epilepsy, and traumatic brain injury).

In this article we first discuss key components relevant to providing appropriate services for students with health care needs. These include individual health care plans, emergency care, and administration of medication, as well as universal precautions. Following is a review of common health conditions of school-aged children and youth (Cross \& Jones, 1996), including food allergies, asthma, cystic fibrosis, diabetes (type 1 and type II), epilepsy, and sickle cell disease. In addition, although less common in children living in the United States than in some countries (e.g., Africa), human immunodeficiency virus (HIV) and acquired immunodeficiency syndrome (AIDS) are included in the discussion. An overview of each condition is provided, including medical management. Finally, we discuss school health care needs and related accommodations that may be made for students with each condition.

\section{WHO ARE STUDENTS WITH HEALTH CARE NEEDS?}

Students diagnosed with various health conditions who attend public schools may require some degree of accommodations to allow them equal access to educational services. Some students, with health conditions determined to adversely affect their educational performance, may be found to be eligible for special education and related services under the Individuals with Disabilities Education Act [IDEA] (1997) eligibility category Other Health Impairment. These students have:

\begin{abstract}
Limited strength, vitality or alertness, including a heightened alertness to environmental stimuli, that results in limited alertness with respect to the educational environment, that-(i) Is due to chronic or acute health problems such as asthma, attention deficit disorder or attention deficit hyperactivity disorder, diabetes, epilepsy, a heart condition, hemophilia, lead poisoning, leukemia, nephritis, rheumatic fever, and sickle cell anemia; and (ii) Adversely affects a child's educational performance (IDEA Final Regulations34 C.F.R. $§ 300.7$ (b) (9).
\end{abstract}

The American Academy of Pediatrics [AAP], Committee on Children with Disabilities, and Committee on School Health (1990a), however, noted that children with chronic health conditions often do not require special education but will need specific health services within the school setting. Students with documented health conditions who do not meet eligibility criteria for Other Health Impairment should receive reasonable accommodation provided under Section 504 of the Vocational Rehabilitation Act.

\section{PLANNING APPROPRIATE HEALTH CARE SERVICES AND RELATED ACCOMMODATIONS}

The American Academy of Pediatrics (AAP) (1990a) recommends close collaboration among school staff, families, and health care providers to plan the provision of student health care. School nurses play a key role in supporting students with health care needs with the child, parents, school staff, and the child's personnel physician and other health care workers to coordinate appropriate services for the student (Williams \& McCarthy, 1995). As two students diagnosed with the same health condition may need very different health care and related accommodations, child-specific information must be obtained from parents or legal guardians and personal physicians. This will facilitate planning appropriate health care services and accommodations for students with chronic health conditions.

School district policies and procedures related to the implementation of first aid, administration of medication, routine health care procedures, and emergency care needed for all students should be in place. Unfortunately, Heller, Fredrick, and Rithmire's study (1997) reported that many schools were without such procedures.

\section{Identifying School Health Services}

School health services are identified within the individual health care plan for students eligible under IDEA, and the health care plan is attached to the student's individualized education program (IEP). Rapport (1996) identified medication delivery, skin care, and catheterization, as well as gastronomy and respiratory care, as examples of healthrelated services and procedures that some students with disabilities may need to benefit from their special education programs. As a result of the seminal related services ruling in Irving Independent School District v. Tatro (1984) the U.S. Supreme Court determined that clean intermittent catheterization did constitute a school health service. A service was to be provided as a "school health service" if three criteria were met:

\footnotetext{
(a) the child be disabled and so as to require special education; (b) without the necessary service during the school day, the child would be unable to participate in an educational program; and (c) the service could be performed by a nurse or other qualified person, but not by a physician. (Rapport, p. 542)
}

Such procedures may be consequently determined to be a "school health service" if in part it is a service that can be provided by a school nurse or other qualified person (IDEA Final Regulations-34 C.F.R. § 300.24(b)(12)).

Although federal regulations specify the need for medical service as it relates to diagnostic evaluations, a clear distinction between required educational health care services 
and medical services has become blurred within the legal system (Janz et al., 1997). For example, Katsiyannis and Yell (2000) noted that several cases since the Tatro ruling, such as Neely v. Rutherford County School (1995), Granite School District v. Shannon M. (1992), Detsel v. Auburn Enlarged City School District Board of Education (1987) and Bevin H. v. Wright (1987), did not reflect the previous standard established in the 1984 Tatro decision. In these cases, the judges seemed to rule on several factors that included (but were not limited to) the expense of the health care services, the potential for liability for the districts in implementing the procedures and that "some of the medical services were potentially life-threatening" (p. 321).

Subsequently, the Supreme Court contributed to the debate over what constitutes a school health care service, ruling in favor of the parents in Cedar Rapids Community School District v. Garret F. in 1999. In this case, the student required numerous health services, such as ventilator monitoring and cleaning, tracheotomy supervision, frequent body repositioning, catheterization, and food/liquid intake assistance, while attending school. The court ruled that the student required these services to attend school; therefore, the medical assistance was considered a related educational health care service.

The Garret F. ruling was aligned with the previous (1989) case, Timothy W. v. Rochester (NH) School District case, which applied "the zero reject principle established by Congress” (Katsiyannis \& Yell, 2000, p. 322).

The comprehensive nature of health care services and plans for students with disabilities has led to school districts and states purchasing liability insurance and developing policy manuals on the administration of these services. For example, "School personnel may be civilly and even criminally liable if they provide services within the scope of nursing practice that have not been properly delegated and supervised by a nurse" (Janz et al., 1997, p. 32). Katsiyannis and Yell (2000), Yell and Shriner (1997) and Yell (1998) provide a comprehensive review of educational court cases and related health care services.

\section{Individual Health Care Plans}

Thies (1999) noted that diabetes, cystic fibrosis, and asthma can each impact children to significantly different degrees. Consequently, individual health care plans should be developed by school nurses, teachers, and other school staff (e.g., nutritionist, physical therapist) in close collaboration with parents and health care providers (i.e., physician, specialty nurses) knowledgeable of a child's condition and needs. Components of an individual health care plan are:

- Child's name, picture, and emergency contact information (family and physician)
- Case manager(s) and/or persons responsible for implementation of treatment with qualifications specified (to include primary treatment contact with multiple backup contacts)

- Diagnosis/description of the condition, health history, including specific symptoms and level of severity

- Ongoing daily treatments including health care procedures and medication administration (location of medication, dosage, times for medication delivery, medication delivery route, side effects, expiration date, school personnel responsible for treatment)

- Monitoring responsibilities (specific roles of school personnel, data-keeping responsibilities and data/record forms, symptoms, and characteristics)

- Emergency procedures (if needed, include on first page of health care plan with bold or highlights), including specific symptoms that indicate an emergency, sequenced list of action(s) to be taken (e.g., accessing specific trained school personnel, medication administration, starting CPR, calling emergency medical service), and monitoring responsibilities (e.g., completing injury report)

- Additional accommodations to be provided, including identification of physical access changes (classroom, equipment, other schools environments), changes in instruction and activities (e.g., rest breaks when fatigued, changes in activity type or length), as well as assistive technology.

To reduce potential liability, it is recommended that school officials obtain a medical release for treatment that is outlined within the child's health care plan (AAP, 1990a). See Porter, Haynie, Bierle, Caldwell, and Palfrey (1997) for forms (i.e., health care plan checklist, health care plan, health care procedures information sheet, physician order for special health care) useful when planning for students with school health care needs.

A health care plan should identify the individuals responsible for implementing and monitoring school health services. Typically, school nurses' responsibilities include monitoring students' general health, dispensing medications and carrying out nursing procedures, managing emergency situations, and providing supervision to health aides (Williams \& McCarthy, 1995). Heller et al. (1997), however, found that in addition to school nurses, teachers, teaching assistants, and parents implemented a range of health care procedures for children within the schools examined. The most common procedures performed were seizure and blood glucose monitoring and medication administration. Those authors noted that training must be provided to those individuals designated to implement such procedures as well as all staff members who are likely to observe potential complications or problems. 


\section{Medication Administration}

Administration of medication often is included within a student's health care plan (Cross \& Jones, 1996). Students' medical needs may require that medication be delivered routinely at school for chronic health conditions (e.g., diabetes, epilepsy, asthma) as well as for acute health problems (e.g., infections associated with cystic fibrosis) (Heller et al., 2000). In these cases, schools have to obtain written parental request to have the medication administered at school, and obtain a signed physician's authorization to have the medication given to the students at school. Additional information related to medication delivery, storage, and common and rare side effects also have to be documented.

School personnel who are routinely responsible for the medication delivery will have to identify and provide appropriate training related to medication delivery, documentation, and monitoring for side effects for each student receiving medication at school. The AAP (1990a) recommended that schools develop policies related to medication administration, storage, and guidelines for student self-administration of medications when appropriate.

The following resources can be used within an initial orientation for school personnel who will be involved with students who receive medication. These people include the staff members directly responsible for delivering medication as well as staff members who will not personally deliver medications but who will be in a position to observe for potential medication side effects.

Assisting Children with Medications at School: A Guide for School Personnel. Denver: University of Colorado Health Sciences Center, School of Nursing, Office of School Health, 1995 (Available from Learner Managed Designs, Lawrence, KS).

This 35-minute video provides a comprehensive overview of medication delivery for teachers and other school personnel who will be responsible for medication delivery. This video reviews the five rights of medication delivery (i.e., right medication, student, dose, route, and time), medication storage, different medication delivery routes (e.g., oral, inhaled, topical), medication delivery documentation, and demonstrates proper medication administration. This video can provide a basic overview for school personnel to be shown prior to their participating in individualized medication administration training related to specific students.

Medications and Procedures for Administration, by K. Heller, L. Wolff, P. Forney, P. Alberto, M. Schwartzman, and T. Goeckel, in Meeting Physical and Health Needs of Children with Disabilities, by K. Heller, P. Forney, P. Alberto, M. Schwartzman, and T. Goeckel (pp. 67-96). Belmont, CA: Wadsworth/Thomson Learning, 2000.

This book chapter provides a comprehensive discussion of medications and includes content on medication descriptions, administration considerations including receiving medications and medication storage. Standard medication delivery procedures are reviewed in detail. Sample medication authorization and medication delivery documentation forms also are provided.

\section{Emergency Care}

The American Academy of Pediatrics (AAP) Committee on School Health (1990b) presented a series of recommendations for emergency care for students in schools. Recognizing that all schools do not hire full-time nurses, the Committee suggested that schools identify specific staff members to be trained and authorized to make urgent care decisions. Schools also should develop and make accessible to school staff an emergency care manual and develop procedures for obtaining emergency medical assistance from the community (e.g., fire rescue squads, ambulances). The Committee also recommended that at least two school personnel be trained to manage emergency situations, in accordance with the school emergency manual, until the school nurse, physician, or other emergency personnel can be located.

Training in basic first-aid, identifying and treating anaphylaxis (allergic reactions), and cardiopulmonary resuscitation (CPR) should be provided and be periodically updated. Emergency medical kits, including materials needed to treat severe allergic anaphylactic reactions, should be stored with medications and made accessible to these trained school emergency providers. Finally, procedures for contacting parents, guardians, or other authorized parties must be in place in conjunction with a procedure for completing incident reports related to any school injury or medical incident. See Porter et al. (1997) for sample emergency plans, emergency telephone procedures, and emergency contact information.

\section{Universal Precautions}

All school personnel should follow universal precautions, as well as infection control procedures when dealing with blood, bodily fluids, and other body substances (vomit, sputum, etc. when blood is seen within the substances) to protect against the transmission of blood-borne infections (e.g., hepatitis B virus, HIV) to school personnel and students (Giardina \& Psota, 1997). Training in the use of universal precautions should be extended to all students, not just those with chronic health conditions.

Protective equipment such as gloves should be used in situations that involve direct exposure (or potential exposure) to blood, skin that has been cut or damaged, mucous membranes, or other bodily substances that may contain blood (Giardina \& Psota, 1997). Because some students are allergic to latex and may have a severe allergic reaction after coming in contact with disposable latex gloves, non-latex gloves should be available (Meeropol, 1997). 
Universal precautions include appropriate cleaning of contaminated surfaces and proper disposal of all contaminated disposable items (e.g., bandages, gauze, tissues). Nondisposable items should be removed from the area and disinfected while using appropriate protective equipment. A puncture-proof container that can be sealed (called a sharps container) should be used in disposing of lancets and needles used by students with diabetes to monitor their blood glucose and administer insulin. Finally, thorough hand washing is recommended especially following removal of gloves (Giardina \& Psota, 1997). All schools should develop and follow standard procedures for handling blood and blood-contaminated materials. Future teacher educators should receive specific training in managing blood and other bodily fluids within their teacher training programs (Ballard, White, \& Glascoff, 1990). Resources that provide more indepth reviews of universal precautions are:

Universal Precautions in Schools: Protection from Bloodborne Diseases. Denver: University of Colorado Health Sciences Center, School of Nursing, Office of School Health, 1996 (Available from Learner Managed Designs, Lawrence, KS).

\begin{abstract}
This 27-minute video provides an overview of universal precautions for school personnel to take to reduce the likelihood of transmission of blood-borne pathogens (e.g., hepatitis B virus, HIV). The video includes a detailed demonstration of proper hand washing to reduce disease transmission to students and school staff and procedures to follow when dealing with student accidents, that introduce blood into the classroom environment.
\end{abstract}

Universal Precautions and Infection Control in a School Setting, by R. G. Giardina and C. E. Psota, in Children and Youth Assisted by Medical Technology in Educational Set$\therefore$ : $s$-Guidelines for Care ( 2 d ed., by S. Porter, M. Haynie, T. Bierle, T. H. Caldwell, \& J. S. Palfrey, pp. 74-78), Baltimore: Paul H. Brookes, 1997.

This book chapter reviews universal precautions and infection control procedures designed to prevent transmission of the hepatitis B virus (HBV), human immunodeficiency virus (HIV), and other infections that can be spread through blood.

Clearly, schools have to develop written policies and procedures related to basic first-aid, medication administration, universal precautions, and emergency care for all students. For students with identified health care needs, key staff members must be fully aware of each child's condition, including the cause or etiology, symptoms of and complications of the condition, and an overview of medical treatment of the condition. Of additional importance is to train personnel in specific health care procedures that individual students need.

\section{FOOD ALLERGIES}

Educators will have students that have mild to severe food allergies, making knowledge of this condition essential. Food allergies arise because of an immune system overreaction to certain substances in food or drink (Asthma and Allergy Foundation of America [AAFA], 2002). True food allergies occur in $3 \%$ to $8 \%$ of children (AAFA, 2002; National Institute of Allergy and Infectious Diseases [NIAID], 2001, June 25) and sometimes are confused with conditions such as food intolerance and secondary food sensitivities (Taylor \& Hefle, 2001).

Food intolerance may be described as an abnormal reaction to certain foods or food components and, unlike a true allergy, does not involve the immune system. Lactose (milk) intolerance is offered as a common example. Lactase deficiency affects approximately one in 10 people (NIAID, 2001, June 25). Secondary food sensitivities may be an effect of another health condition (such as sensitivity to lactose resulting from a gastrointestinal disorder or medicationinduced food sensitivities) (Taylor \& Hefle, 2001).

The Asthma and Allergy Foundation of America (2002) reports that "severe, life-threatening reactions are more common with allergies to peanuts, tree nuts, shellfish, fish and eggs" (p. 2) and more severe reactions are noted in individuals with asthma. The latency of the reaction, as well as the severity, depends on the individual's level of sensitivity, amount of food ingested, and how the food is prepared.

Reaction typically occurs within minutes, or up to 1 to 2 hours after the food has been ingested (AAFA, 2002). The eight categories of foods that contribute to more than $90 \%$ of allergic reactions are (Taylor \& Hefle, 2001, p. 73):
1. Wheat (gluten products)
2. Eggs and egg products
3. Milk and milk products
4. Tree nuts and nut products
5. Shellfish
6. Fish and fish products
7. Peanuts and peanut products
8. Soybeans and soy products

Children frequently outgrow allergies to these foods by age 3; however, peanuts, tree nuts, and shellfish typically cause lifelong reactions (Coutts, 2000; NIAID, 2001, June 25). Symptoms of allergic reactions to food include (Coutts, 2000; Formanek, 2001; NIAID, 2001, June 25):

- Tingling sensation in the mouth

- Difficulty breathing

- Vomiting

- Drop in blood pressure

- Swelling of tongue and throat 
- Hives

- Abdominal cramps and/or diarrhea

- Loss of consciousness

\section{Medical Management}

Medical management begins with strict avoidance of any food that contributes to an allergic reaction as very small amounts can produce severe symptoms (Coutts, 2000; Formanek, 2001). Because of the severity of the reaction in individuals who are allergic to peanuts, the Department of Transportation ordered airlines to set up peanut-free zones, and some schools also followed this recommendation (Hartocollis, 1998). A study by Nowak-Wegrzyn, ConoverWalker, and Wood (2001), however, found that eliminating food allergic reactions in schools is difficult, even in settings where special accommodations have been made for individuals with known food allergies.

Based on the Food and Drug Administration (FDA) guidelines, labeling of food products has become more detailed, with some warnings that indicate when even small traces of peanuts, soy, milk, eggs, or other allergens may be present. Even so, ineffective labeling and identification procedures can contribute to accidental exposures because potential allergens found in peanuts, eggs, and milk may be contained in products not normally associated with those foods (NIAID, 2001, June 25). For additional precautions regarding interpretation of food labels and food preparation, readers are directed to http://www.foodallergy.org/research. html (Food Allergy and Anaphylaxis Network).

Depending on level of severity of an allergic reaction, an oral antihistamine may be prescribed by a child's physician to be administered for reactions that involve mild hives, swelling, or flushing (Hay, Harper, \& Coursen, 1994; NIAID, 2001, June 25). Although most children do not have life-threatening allergic attacks, some children do experience a particularly severe allergic reaction known as anaphylaxis (Food Allergy and Anaphylaxis Network, 2002, January 2). An anaphylaxis reaction may occur as result of exposure to, or ingestion of, a specific food, medication, or insect sting (Hay et al., 1994). Anaphylactic reactions can be fatal even when they begin with mild symptoms, and immediate treatment with epinephrine (adrenaline) followed by medical attention is essential (Dibs \& Baker, 1997). If epinephrine has been prescribed for a child at risk for severe allergic reaction to food or other substances, access must be readily available at all times, including recess and school trips.

According to The Food Allergy Initiative (n.d.), the Epi Pen typically is prescribed as a means of injecting needed medication and reversing the symptoms of anaphylaxis. The Initiative recommended that "epinephrine be administered as soon as possible to hold off symptoms, buying time to get to the emergency room for more care" (p. 1). Educators should follow the three R's for treating anaphylaxis:

1. Recognize symptoms.

2. React quickly.

3. Review what happened to prevent it from recurring.

Readers are directed to http://www.foodallergy.org//anaphylaxis.html (Food Allergy and Anaphylaxis Network) and http://foodallergyinitiative.org (Food Allergy Initiative) for detailed information on administration of epinephrine via an Epi Pen; however, personnel designated to administer the Epi Pen, as well as other prescribed medication, must be trained by a medical professional. As a caution, failure to administer epinephrine promptly has been linked to several fatalities and near fatalities (Hay et al., 1994).

\section{School Health Care and Related Accommodations}

The physician should provide guidelines for exposure to foods that result in intolerance and sensitivity and should approve any health care plan for a child with food allergies. Even though the child may be well between episodes, the importance of a structured written health care plan, including a plan for emergencies, as a component of the IEP or Section 504 plan is stressed (Hay et al., 1994). In addition to the components already discussed, the individual health care plan for a child with an allergy should include:

- The substance or food the child is allergic to, as well as a detailed plan for food avoidance

- Location(s) of the Epi Pen, instructions for administration, notation regarding expiration date, and directives regarding medical follow-up

- The personnel trained in CPR and administration of the Epi Pen

- A list of foods to be avoided, as well as acceptable foods.

Older children at risk for an anaphylactic reaction may have been trained to self-administer medication and carry a syringe of epinephrine in a purse, fanny pack, or backpack. Because this may conflict with school policy on drugs, this must be addressed by the educational team that includes school personnel, the family, and the child's physician. When the individual does not carry epinephrine directly, the medication should be stored in multiple locations within all school buildings, and the size of the building and time required for access considered.

All educators must be knowledgeable regarding the symptoms of both mild and severe allergic reactions including anaphylaxis. Posting information on symptoms and response procedures in various locations throughout the building is recommended, and this information should be 
included as standard within district staff development. Wearing a medical alert bracelet or necklace stating the nature of the allergy for any individual at risk for an allergic reaction is also recommended (NIAID, 2001, June 25).

Modifying recipes or menus was a common accommodation reported by more than $50 \%$ of school districts (Gandy, Yadrick, Boudreaux, \& Smith, 1991). That study indicated that school food service personnel need additional training to serve these students appropriately. The family and physician should guide the school team in developing a Safe Food and Prohibited Foods List to be attached to the health care plan. To reduce the possibility of exposure, educators must communicate with families of children within the school and request that foods with the offending allergen not be sent to school as treats.

In school settings where foods such as peanuts have been eliminated or contained in zones, caution still is recommended because unknown traces of the allergen may be hidden in foods or a food may have become inadvertently contaminated. Formanek (2001) reports that $25 \%$ of 73 varied food samples tested positive for peanuts; however, peanuts were not listed on the labels, so companies had unintentionally introduced allergens into some foods through improper cleaning of utensils and production equipment. Further, one brand of a product may be safe while another is not, and foods previously determined to be safe may have changed ingredients without changing packaging (Formanek, 2001). These findings suggest the need for extreme care in food preparation as well as cleaning routines in the school setting.

\section{ASTHMA}

Asthma is a chronic lung condition characterized by inflammation, obstruction, and increased sensitivity of airways (Aronson, 1995). This condition contributes to significant rates of school absenteeism (Getch \& NeuharthPritchett, 1999; Environmental Protection Agency [EPA] 2001, November 27). In 1981, 3\% of children in the United States were diagnosed with asthma, and in 1998 asthma had been diagnosed in $5 \%$ of U.S. children (Federal Interagency Forum on Child and Family Statistics, 2001). But Raj, Mishra, Feinsilver, and Fein (2000) and Rana, Jurgens, Mangione, Elia, and Tollerud (2000) caution that asthma may be inadequately diagnosed, resulting in an underestimate of its prevalence, and state the need for diligence in proper identification and treatment. Other sources have indicated that asthma affects as many as $7 \%$ to $10 \%$ of children (Aronson, 1995; Lung Association, 2002, July 19).

Individuals with this condition have hypersensitive airways, and asthma symptoms may be triggered by food, exercise, weather change, viruses, or environmental substances that irritate the lungs (Celano \& Geller, 1993; Simeonsson,
Lorimer, Shelley, \& Sturtz, 1995). When the person is exposed to a trigger, additional mucus is produced, which subsequently clogs air tubes. The air tubes swell and muscles within the tubes tighten, causing the tubes to narrow or constrict.

Some asthma triggers are:

- Food allergens

- Respiratory infections and viruses

- Exercise (overexertion)

- Cold air

- Environmental allergens (chemicals, gases, cigarette smoke, dust, feathers, mold)

Symptoms and warning signs of asthma include:

- Shortness of breath

- Nasal flaring

- Complaints from child regarding pain, tightness in chest, and/or difficulty breathing

- Wheezing or chronic, persistent cough

- Irritability and/or restlessness

- Blue tint of lips, nails, or change in face color

- Rapid breathing

- Fever and/or headache

- Watery or glassy eyes and sneezing

- Sore throat, itchy throat or chest

- Drop in peak flow reading (Aronson, 1995; Celano \& Geller, 1993; Getch \& Neuharth-Pritchett, 1999; Schwartz, 1999; Simeonsson et al., 1995)

Increasing hospitalization and mortality rates are being reported among children with this condition (da Costa, Rapoff, Lemanek, \& Goldstein, 1997), with symptoms of varying severity. When individuals experience a severe attack, talking and breathing can become difficult (American Lung Association [ALA], 2002a; The Lung Association, n.d.).

\section{Medical Management}

Asthma attacks may have to be treated with rest, medications, reductions and restrictions in physical activities, and a trip to a doctor or hospital may be required (Aronson, 1995; Celano \& Geller, 1993; Getch \& Neuharth-Pritchett, 1999; Simeonsson et al., 1995). A variety of both long-term and short-term control medications are available for individuals with asthma, including inhaled, liquid, and oral medications. Long-term medications, designed to control and prevent asthma symptoms, include cromolyn, inhaled steroids, and nedocromil. Short-term or quick-relief medications are designed to be taken when symptoms such as chest tightening, wheezing, and coughing first appear; these medicines include albuteral, prednisone, and ipratropium bromide. Readers are 
directed to the brochure "Controlling Your Asthma," published by the National Heart, Lung, and Blood Institute [NHLBI], National Institutes of Health (n.d.), for a listing of common long-term and quick-relief asthma-control medications.

Some asthma medications are inhaled. Possible benefits are smaller medication dosages and medication directed to the needed area without traveling through the stomach and circulatory system (Aronson, 1995). Both metered-dose inhalers and nebulizers may be utilized to deliver inhaled asthma medication. A nebulizer is a machine that creates a mist and delivers medication that is inhaled via a mask or breathing pipe. The medicine is placed in a holding chamber and delivered over a specified period of time.

Individuals with asthma may use metered-dose medication therapies designed to deliver a standard dose of medication to be quickly inhaled. This requires that a child coordinate his or her breathing to inhale at the exact time the medication is delivered, to be able to receive the entire dose of medication. As this can be difficult for some children to accomplish, spacers are available for use with metered-dose medications. Spacers are specially designed chambers or bags into which the medication is first dispensed. The medication then mixes with air within the spacer, allowing the individual to inhale and receive the medication more easily (Cystic Fibrosis Foundation [CFF], 1997a, March).

A peak flow meter, a portable hand-held device used to measure how air flows from the lungs, also may be utilized by individuals with asthma. Peak flow meters identify a drop in the flow of air to allow for a determination of whether medication has to be administered to prevent further symptoms. Readings are compared to acceptable levels established when the child is well to determine when medication is warranted (Aronson, 1995).

\section{School Health Care and Related Accommodations}

From an early age, the child with asthma and the caregivers must become familiar with asthma triggers and structure the environment to avoid known allergens and offending substances. School personnel have to be aware of specific asthma triggers that are likely to cause an asthma attack and ways to reduce or eliminate exposure to triggers. Schwartz (1999) recommends that schools conduct cleaning and repairs to reduce and/or eliminate asthma triggers. These efforts may include removing cleaning supplies and plastic furniture and carpeting that may emit toxic fumes, as well as thorough cleaning of the site-in particular, ventilation systems - to reduce exposure to mold, dust, chalk dust, animal dander, cockroaches, and other triggers.

Air quality should be monitored regularly. Sensitivity in scheduling to keep students away from known triggers such as chemicals during cleaning regimens or contained within art supplies may also be beneficial. Preventing exposure to individuals who have respiratory infections is another suggestion (Simeonsson et al., 1995).

Educators also must be sensitive to the needs of students who are susceptible to pet allergens and reduce or eliminate exposure in the school setting. They, too, should be aware of the possibility of exposure via class peers. A study by Almqvist et al. (1999) found an association between the levels of air-borne cat allergens and the number of cat owners in a classroom. This study indicated that allergens may be transferred through direct contact with the pet owner, contact with the pet owner's clothing, or contact with allergen deposits at sites within the classroom.

Other environmental considerations include sensitivity to the effect of cold, dry air, and exercise. Recommendations include encouraging the child to wear a covering over the nose or face in cold weather, ensuring that the child has received the appropriate medication prior to playing outside, and requiring rest after play. In addition, teaching the child to monitor emotional behaviors such as laughing, yelling, or crying may be helpful (Simeonsson et al., 1995).

A management plan based on individual health needs should be developed for each child diagnosed with asthma, for utilization within the school. Information related to peak flow meter use, medication administration, medication delivery devices such as a nebulizer, inhaler, and spacer and other reasonable accommodations (e.g., reducing exposure to triggers, planning for activity restrictions and alternative activities when needed) should be included. The plan should state treatment procedures unique to the individual and be approved by the family and the physician. Specific symptoms that warrant family contact and emergency treatment for a child with asthma should be detailed.

An action plan form that might support the educational team is available by accessing http://www.lung.ca/asthma/ magage/action.html (The Lung Association, n.d.). In addition, the National Heart, Lung, and Blood Institute (n.d.) has developed an asthma action form that can be used to outline routine daily asthma treatment, as well as procedures to follow for mild and more severe asthma symptoms.

For any child receiving medication, teachers must have information on, and monitor for, possible side effects (both common and rare) of all medications the child is taking either at home or while at school. For additional information regarding the use of medication-delivery devices and peak flow meters, medications, and management of asthma, access http://www.lungusa.org/ (American Lung Association). Educators and other school personnel also are directed to "Controlling Your Asthma" (NHLBI, n.d.) for detailed descriptions on correct use of metered-dose inhalers and peak flow meters. A peak flow record chart can facilitate the tracking of peak flow results across days to assist in ongoing treatment planning (see ALA, 2002b). 
Celano and Geller (1993) noted the functional relationship between childhood asthma, school absenteeism, and poor academic performance. Diette et al. (2000) found that children with asthma symptoms associated with nocturnal awakenings had both decreased school attendance and academic performance. Given the possible psychosocial effects, as well as the potential for fatigue and missed instruction, a positive behavioral support plan may be warranted for some students with asthma.

In addition, a study by da Costa et al. (1997) indicated the potential for token economy systems to increase adherence to a treatment regimen. Given the prevalence of students with this condition in the school population, as well as the potential severity of the symptoms, educators will have to collaborate with the family and physician, participate in staff-development training, and receive ongoing administrative support to meet the needs of students with asthma.

\section{CYSTIC FIBROSIS}

Cystic fibrosis (CF) is an inherited genetic condition that affects the digestive tract as well as the lungs of individuals who have the condition. Those diagnosed with cystic fibrosis have inherited two copies of a defective gene, one from each parent, which causes the condition. Individuals who have only one defective gene are carriers of the condition but are not actively affected by cystic fibrosis (Cystic Fibrosis Foundation [CFF], 2002, March 8). Approximately 30,000 people in the United States have cystic fibrosis (CFF, 2001a, December; Mayo Clinic, 2002, May 14; National Institute of Diabetes \& Digestive \& Kidney Diseases [NIDDK], 1998, February 12). Estimates are that 1,000 infants are born each year with CF (NIDDK, 1998, February 12) and 1 in 31 individuals in the United States are unaffected carriers of the condition (CFF, 2001a, December).

The condition is seen more often in Caucasians than in African-Americans (CFF, 2002, March 8); CF is found in 1 in 3,000 Caucasian infants (NIDDK, 1998, February 12) and in an estimated 1 in 14,000 African-American live births (cited in FitzSimmons, 1993). Data reported by FitzSimmons (1993) from the National Cystic Fibrosis Patient Registry indicated that, in $1990,95 \%$ of the 17,857 registered patients were Caucasian. Approximately $54 \%$ of all registry patients were male, and $61 \%$ were 15 years of age or younger. The national registry includes approximately $75 \%$ of all diagnosed cases of CF in the United States.

Specifically, CF causes the body to produce "abnormally thick, sticky mucus, due to the faulty transport of sodium and chloride (salt) within the cells lining organs such as the lungs and pancreas, to their outer surfaces. This abnormal mucus clogs the lungs and leads to life-threatening lung infections" (CFF, 2001a, p. 1). These respiratory infections are frequent and at times lead to hospitalizations (NIDDK, 1998, February 12) and possible eventual respiratory failure (Mayo Clinic, 2002, May 14). People with CF have difficulty combating a variety of bacterial infections, most commonly pseudomonas aeruginosa. Individuals diagnosed with cystic fibrosis have a salty taste to their skin (Mayo Clinic).

People with $\mathrm{CF}$ also have "insufficient amounts of digestive enzymes for normal digestion. Pancreatic insufficiency causes foul-smelling, bulky bowel movements, malnutrition and slowed growth and development" (NIDDK, 1998, February 12, para. 7). In addition, individuals with CF typically have persistent coughs and wheezing, recurring chest and sinus infections, clubbed (rounding) fingers and toes, and polyps (growths) in the nasal passages (Mayo Clinic, 2002, May 14).

Cystic fibrosis at times affects other parts of the gastrointestinal system (e.g., bile ducts in the liver) as well as the reproductive organs; some women and most men with CF are unable to conceive children (NIDDK, 1998, February 12). Nevertheless, specific symptoms and signs of $\mathrm{CF}$ vary based on severity of the disease and age of the person with CF (Mayo Clinic). Cystic fibrosis also is associated with medical complications of obstructions of the intestines, diabetes, and cirrhosis (FitzSimmons, 1993).

\section{Medical Management}

Prior to the last decade, cystic fibrosis typically resulted in premature childhood death from respiratory failure (NIDDK, 1998, February 12). Many individuals with cystic fibrosis, however, are now living into their 30s (Mayo Clinic, 2002, May 14), 40s, and 50s (FitzSimmons, 1993). The gene responsible for causing CF was identified in 1989 , and research now is being conducted to identify new drugs for treating symptoms (i.e., lung inflammation and infections) (CFF, 2001c, December) and gene therapy targeted at correcting the defective cystic fibrosis cells (CFF, 2001b, December).

Medical management of $\mathrm{CF}$ is targeted at fighting infections, decreasing sputum in the lungs, improving lung functioning, and maintaining appropriate calorie intake and overall nutrition. Medications prescribed to treat infections include oral, inhaled, and intravenous (i.e., in the vein) antibiotics (Mayo Clinic, 2002, May 14). Pancreatic enzymes also are prescribed to assist with digestive problems, and increased calorie intake is recommended. DNase, a natural enzyme delivered through an aerosol spray, has been developed to reduce the stickiness of the excessive mucus that persons with CF produce (NIDDK, 1998, February 12).

Individuals with cystic fibrosis need daily manual chest physical therapy (CPT) of the back and chest to help them dislodge and cough up excessive lung secretions (NIDDK, 1998, February 12). Inhaled antibiotics and bronchodilators often are used along with CPT. As an alternative to manual 
percussioning done during CPT, a device called a "flutter" has been developed for use in loosening mucus (CFF, 1997b).

People with CF whose lung functioning is significantly diminished (i.e., the condition is predicted to lead to death in 2-3 years) may be considered for a lung transplant from a donor who does not have CF. Following the transplant, the new transplanted lungs will not have CF; however, CF will still affect the individual's pancreas, sinuses, reproductive system, and digestive tract. After a transplant, the individual will be placed on immunosuppressive medications to fight organ rejection (CFF, 1999, December).

Henley and Hill (1990) indicated that the child's compliance with prescribed therapy for cystic fibrosis (e.g., CPT, medication) is critical for successful home management of the condition. Those authors recommended that the children and their families be well informed about the condition, including appropriate times for medication delivery, the need for pancreatic enzyme supplements with all meals and snacks, and physical therapy (i.e., CPT).

\section{School Health Care and Related Accommodations}

Children with CF may require the delivery of oral and/or inhaled antibiotic medications during the school day to improve their lung function, to fight infections, and in some cases to fight against organ rejection (post lung transplantation) (CFF, 1999). Consequently, this requires identifying at least two individuals to be trained to deliver the student's medication(s), operate and clean devices used for medication delivery, and receive information related to the medication's side effects.

Students with cystic fibrosis may use metered-dose medication delivered through a small inhaler with or without a spacer (CFF, 1997a, March). Inhaled medications also may be delivered via a disposable or reusable nebulizer. WilliamsWarren (1998) provides a detailed summary of steps needed to clean and maintain nebulizers. Appropriately cleaning and disinfecting/sterilizing the nebulizers increases their effectiveness and decreases the likelihood of contamination and contracting new infections from bacteria. Because of the potential side effects that can develop from different types of medications mixing when delivered from a common nebulizer, specific medications may have to be dispensed by a nebulizer that is to be used to dispense only that particular medication (Williams-Warren).

Along with the delivery of medications, chest physical therapy (CPT) may have to be provided for students with $\mathrm{CF}$ during the school day, as prescribed by the student's primary physician. A detailed informational summary of CPT developed by the Cystic Fibrosis Foundation (1997b) overviews the anatomy of the lung, describes CPT techniques (including bronchial drainage, percussioning, vibration, deep breathing, and coughing) and includes instructions for the various bronchial drainage positions that may have to be used with a student who has cystic fibrosis. This summary is available from the Cystic Fibrosis Foundation (see "Additional Sources of Information"). Required chest percussioning can be done by a nurse or a teacher who has received appropriate training. Students also should be encouraged to increase their fluid intake, which assists in loosening mucus (Mayo Clinic, 2002, May 14).

Exercise for individuals with cystic fibrosis helps to alleviate shortness of breath and improves the clearance of mucus (Luder, 1997). Although people with cystic fibrosis can exercise in the heat, they will lose more salt as a result of their exercise than would someone without the condition. Consequently, individuals with CF should increase their liquid intake during exercise.

Cystic fibrosis also can negatively impact learning in that it has been associated with a depressed mood, anxiety, memory and concentration problems, and fatigue (Thies, 1999). After their study of 76 children with CF found $22 \%$ of the children to be more than a grade level below in reading and $14 \%$ below a grade level in mathematics, Thompson et al. (1992) concluded that some children with CF will require educational evaluation and interventions to promote positive adult outcomes related to employment. Finally, students with CF may have more school absences because of illnesses and hospitalizations related to lung infections and serious respiratory complications.

\section{HIV AND AIDS}

Human immunodeficiency virus (HIV) can be transmitted through unprotected sexual contact with individuals who have HIV, or by sharing needles with infected persons, or from contact with infected blood from mucous membranes or broken skin. The virus also can be passed from an infected mother to a child prenatally, during labor and delivery, as well as through breastfeeding (Hale, 1997).

Although in the past HIV also was spread through blood transfusions and other blood products that were infected with the virus, improved screening of blood and special heat treatment for blood products has significantly reduced the likelihood of these routes of transmission. Research to date indicates that HIV is not spread through urine, feces, tears, sweat, or saliva. HIV is not transmitted through daily casual contact such as that within schools, given that no bodily fluids or blood are exchanged (NIAID, 2001a, May).

Tests can be done to determine the presence of the HIV tests in an individual's blood. If the virus is identified, that individual is stated as being "HIV-positive." Early symptoms that sometimes appear within the first several months after HIV infection are flulike but may be mild and consequently overlooked (NIAID, 2001a, May). 
AIDS is caused by the presence of HIV and may often be identified only after a person has been diagnosed with unusual cancers or infections-called opportunistic infections - suggestive of a severe immunodeficiency (NIAID, 2001, May). A common one is pneumocystis carinin pneumonia (PCP) (Hale, 1997). As of December 2000, 4,061 cases of AIDS in adolescents aged 13-19 had been reported to the CDC (NIAID, 2001b, October).

The decreased immune system functioning can cause a variety of neurological complications including nerve, brain, and spinal cord damage, which can lead to encephalitis and meningitis, dementia, strokes, headaches, and behavioral changes. Confusion, low-grade fevers, seizures, vision loss, and memory and cognition deficits also may be seen. Neurological symptoms are mild initially but can increase in severity in the later stages of AIDS. Finally, cancers and opportunistic infections are typical manifestations of persons with AIDS (National Institute of Neurological Disorders and Stroke [NINDS], n.d.).

\section{Medical Management}

Currently, AIDS has no cure. Various antiretroviral medications (protease inhibitors) are used to slow the progression of HIV (Brown, Lourie, \& Pao, 2000). Other drugtreatment options are available to prevent opportunistic infections and to fight AIDS-related cancers, dementia, and infections (NINDS, n.d.). The health of children with HIV can be seriously compromised by infections and common illnesses of childhood (e.g., rubella, pneumonia, skin infections) and must be treated quickly (Beverly, 1995). The likelihood of children with HIV getting common contagious childhood diseases (e.g., measles, chicken pox) can be reduced by their receiving appropriate immunizations (Task Force on Pediatric AIDS, 1991).

\section{School Health Care and Related Accommodations}

Confidentiality policies and practices vary across school districts (Lavin et al., 1994). Hale (1997) noted that parents do not have to disclose that a child enrolled in a public school has HIV. The Task Force on Pediatric AIDS (1991) noted that confidentiality issues will remain critical "as long as HIV and AIDS are stigmatizing" to the families (p. 646). In some cases families may choose to disclose the child's HIV status to only a few key school personnel (e.g., school nurse, primary teacher, principal). In these instances confidentiality of the information provided by the parent must be maintained by those individuals with information about the child's health condition shared only among the specific individuals identified by the parents. The Task Force on Pediatric AIDS (1991) asserted that "it is essential that confidentiality be maintained by limiting disclosures and disclosing information only with the informed consent of the parents or legal guardians and age-appropriate assent of the student" (p. 647).

Given that parents or guardians may not disclose that a child is HIV positive and due to the fact that some individuals within a school environment (i.e., students as well as school staff) may actually be unaware that they have HIV, universal precautions should be used whenever dealing with blood or bodily fluids from any child or staff member in a school. These would include wearing a protective barrier (e.g., latex or rubber gloves) when dealing with a bleeding injury. Additionally, the sharing of such items as razors, toothbrushes, or any other item that might be contaminated with blood or bodily fluids should also not be allowed in school settings (Hale, 1997). Lavin et al. (1994) reported that the degree of compliance in schools to universal precautions was variable even though most larger districts had documented procedures and had provided staff training. Barriers to compliance to universal precautions identified included financial constraints, limited access to facilities for hand washing, and unwillingness of school administrators to supply needed gloves and other supplies.

During school hours these students may have to routinely take a variety of medications (Task Force on Pediatric AIDS, 1991), and many of the antiretroviral medication regimens are complex in nature (Brown et al., 2000). These medications absolutely must be taken as directed as missed dosages can lead to viral resistance (Brown et al., 2000). Because students with AIDS may become seriously fatigued arrangements may have to be made for planned breaks and additional opportunities to rest when needed, along with restrictions on specific physical activities.

Students with HIV tend to be absent from school more often than other students, as a result of acute illnesses, doctors' visits, and hospitalizations (Grubman et al., 1995). Care should be taken to limit the exposure of students with AIDS to classmates' common childhood illnesses (Kelker, Hecimovic, \& LeRoy, 1994). Some students who are HIV-positive may require special education, but this should be "determined by their learning needs, rather than their HIV status" (Lavin et al., 1994, p. 29). Students who are HIV-positive and those who have AIDS might benefit from counseling.

Kelker et al. (1994) provided a series of suggestions for supports for students with AIDS in schools. For instance, when the parent has allowed information about the child's condition to be shared with classmates, the students might send cards to the child during times of absences because of illness or hospitalizations.

Health education must address bereavement issues related to AIDS (Giardina \& Psota, 1997). The school staff should receive initial and updated inservice training on HIV, with a focus on universal precautions and confidentiality issues (Lavin, 1994). HIV/AIDS education programs should be 
implemented in all schools to further the knowledge of students and school staff regarding methods of transmission and methods of prevention (American Academy of Pediatrics, Committee on Pediatric AIDS, 1998). Such training may facilitate the acceptance of students with HIV within schools (Lavin et al., 1994).

\section{DIABETES}

Diabetes is a chronic disorder affecting approximately 125,000 children in the United States (Preboth, 2000). Type 1 diabetes, often referred to as insulin-dependent diabetes or juvenile diabetes, is a disease in which the body fails to produce insulin, a hormone needed for the body to process sugar (glucose) obtained from ingested foods. Type 1 diabetes typically is diagnosed in childhood or adolescence and often is caused by an autoimmune condition that destroys cells in the pancreas that produce insulin. Without the needed insulin, the body cannot process glucose effectively and the level of blood sugar can become dangerously high.

Every year 13,000 children within the United States are diagnosed with type 1 diabetes (National Diabetes Education Program [NDEP], 2002, February). Type 1 diabetes is associated with increased school absences, health care contacts, and reduction in daily activities (Levetan, 2001).

A second form of diabetes, non-insulin-dependent diabetes or type 2 diabetes has been viewed as affecting primarily adults and often is referred to as adult-onset diabetes. Increasing numbers of children, however, are being diagnosed with this type of diabetes (Vargas et al., 1999). At increased risk for type 2 diabetes are children who are obese (i.e., who weigh more than $20 \%$ above ideal weight), have close relatives with type 2 diabetes, are African-American, Hispanic, Pacific-Islander, or American Indian, and have acanthosis nigricans (dark, thickened skin on the neck) (Touchette, 2000).

Type 2 diabetes occurs due to the body's resistance to insulin (Hansen, Fulop, \& Hunter, 2000) in that the body cannot adequately use its insulin. The American Diabetes Association (ADA) has recommended that the terms type 1 diabetes and type 2 diabetes be used to differentiate the two main types of the disease (National Institute of Diabetes and Digestive and Kidney Diseases [NIDDK], 2000b, April).

Individuals with diabetes can have either hypoglycemia (low blood sugar) or hyperglycemia (high blood sugar). Hyperglycemia (high blood sugar) develops slowly and is characterized by "malaise, fatigue, warm and dry skin, deep breathing, sweet or fruity odor to breath, drowsiness, excessive thirst, and coma" (Yousef, 1995, p. 49). It can be caused by insufficient insulin, illness, or stress (ADA, n.d., b). In contrast, hypoglycemia (low blood sugar)_-also called an insulin reaction-develops rapidly, with symptoms that might include "headaches, sudden changes in behavior, nausea and vomiting, blurred vision, restlessness, pallor, profuse sweating, excessive hunger, cold hands and feet, convulsions, and comas" (Yousef, 1995, p. 49). Hypoglycemia can be caused by excessive insulin, strenuous energy output, and insufficient food or failing to eat after taking insulin (ADA, n.d., c; Yousef, 1995).

Individuals with diabetes can develop diabetic ketoacidosis, a condition in which blood glucose is highly elevated, which results in the build-up of keytones (waste products produced when the body burns fat instead of glucose for energy) in the person's blood. Keytones are eliminated in the urine (ADA, n.d., b). Ketoacidosis can lead to severe dehydration, loss of consciousness, coma, and even death (Touchette, 2000).

Individuals with diabetes can have a range of serious complications when their blood sugar is not kept within normal levels across time. These include heart disease, kidney failure, eye damage (which can lead to blindness), nerve damage, limb amputations, as well as premature death (American Diabetes Foundation [ADA], 2002, February 6; NDEP, 2002, February; Touchette, 2000).

\section{Medical Management}

Individuals with diabetes will require daily blood glucose monitoring, management of food intake and exercise, and in some instances oral medication or daily insulin administration. Type 1 diabetes is generally managed by balancing insulin (NDEP, 2002, February), food intake, and exercise. Individuals with type 2 diabetes often can manage to keep their blood glucose controlled (within normal levels) through exercise and diet; increased exercise and reduced fat and sugar intake are recommended (Hansen et al., 2000; Touchette, 2000), but, if needed, oral medications such as metaformin (glucophage) or sulfonylureas may be prescribed. When oral medications are ineffective, insulin is prescribed for some individuals with type 2 diabetes (Hansen et al.).

All children with diabetes must have their blood glucose levels monitored frequently. Blood glucose monitoring is done by a finger stick test, typically prior to and after eating each meal, before and after exercising, and as additional circumstances dictate. Blood glucose monitoring is done using a glucose monitor, a lancet, and glucose test strips. To conduct a blood glucose test, a lancet is used to pierce the skin, often from a fingertip, to obtain a small sample of blood that is dropped onto a test strip. The test strip is read by a glucose meter, which displays a reading of blood glucose levels (ADA, n.d., a).

Target blood glucose levels before breakfast and meals are typically $80-120 \mathrm{mg} / \mathrm{dl} ; 2$ hours or less after a meal, 180 $\mathrm{mg} / \mathrm{dl}$ or less; and immediately prior to bedtime, 100-140 
mg/dl (NIDDK, 2000c, February); however, physicians identify individual glucose targets for each patient. Many glucose meters now have the capability to store a large number of test results (e.g., 180, 450) within the meter memory and to average blood glucose levels across various time periods (e.g., 1, 2, 3, or 4 weeks, 2 weeks, or 30 days) (ADA, 2002).

If individuals require insulin as part of their daily diabetes management program, syringes as well as insulin injectors, insulin pens, external pumps, and skin patches may be used to administer insulin (see NIDDK, 2000a, February). Insulin can be administered using syringes, injectors, and pens under the skin at various body locations (e.g., thighs, abdomen, arm).

Six different types of insulin are available:

1. Rapid-acting insulin (insulin lispro, Humalog and insulin aspart, Novolog)

2. Short-acting insulin (Regular $[R]$ insulin)

3. Intermediate-acting insulin (NPH $[\mathrm{N}]$ or Lente $[\mathrm{L}]$ insulin)

4. Long-acting insulin (Ultralente $[\mathrm{U}]$ insulin)

5. Very long-acting insulin (insulin glarine, Lantus)

6. Premixed (contains a mixture of NPH insulin and Regular insulin).

The types of insulin vary in terms of how quickly they will start to work, the time taken to lower blood sugar, and the length of time for the insulin to finish working (NIDDK, n.d.). The physician determines the specific types of insulin, amounts to be administered based on specific food intake, frequency and times of routine administration, and amount of insulin to be administered to treat episodes of hyperglycemia. In addition, the physician makes recommendations concerning times to test for keytones.

The physician also determines a specific protocol to be followed when the child's blood sugar is below the normal range. Cases of hypoglycemia may require different treatment protocols depending upon how low the child's blood sugar is. The physician might direct that the child be given a source of sugar such as orange juice, candy, other food items with high sugar content, or chewable glucose tablets. In other instances, a physician might prescribe a glucagon injection. Glucagon is available by prescription only and comes in a kit with a syringe and needle, glucose, and directions for preparing and injecting the glucose. Glucagon kits have expiration dates and should be appropriately discarded after they have expired.

\section{School Health Care and Related Accommodations}

The American Diabetes Association (ADA) report that many school personnel do not have adequate knowledge of diabetes and suggest that the child's parents, health care providers, and school personnel develop an individualized diabetes care plan (Preboth, 2000). The recommended components are:

- Procedures for blood glucose monitoring (including scheduled times and frequency, and situations that call for additional testing)

- Food intake while at school (including types and amounts of foods for meals and snacks, times for meals and snacks)

- Insulin administration (including storage requirements, prescribed dosages for specific blood glucose levels, injection sites and times)

- Symptoms of hyperglycemia (high blood sugar) and hypoglycemia (low blood sugar)

- Treatment protocols to be followed for hyperglycemia and hypoglycemia

- Keytone testing and treatment for high keytone levels.

Identified key personnel (e.g., nurse if available, classroom teacher) will have to receive training in related diabetes health care procedures including blood glucose testing, medication administration (including giving oral medications or insulin shots, programming an insulin pump), and keytone testing. In addition, these staff members should receive training in recognizing and treating hypoglycemia and hyperglycemia as specifically prescribed by the child's physician.

Many students are comfortable with having the glucose testing done in the presence of classmates, but others want to have this done in private. Privacy is the norm, particularly when insulin is administered on the thigh, abdomen, or other body area that normally is covered by clothing.

Because the types of insulin vary in the rapidity and duration of their effects, diabetes management information and training must be specific to each student. Furthermore, one student might use syringes for insulin injection, another an insulin injector, and a third an insulin pump that must be programmed to release insulin.

Some students are taught to self-manage their condition (e.g., how to test blood glucose, administer insulin). The diabetes management plan should describe the extent of their involvement in managing their diabetes care while at school. For example, students who plan to exercise may need to eat a snack after exercising or even during exercise to prevent low blood sugar.

Children with type 1 diabetes usually need a higher level of insulin to manage their condition when they go through puberty (Rosenbloom, 2001). Therefore, school personnel should inform the parents of increased episodes of hyperglycemia. As hyperglycemia also occurs when children 
become ill, appropriate hand washing and use of universal precautions may help to decrease the spread of contagious conditions (such as the common cold).

For field trips, all materials needed for blood glucose monitoring and insulin administration must accompany the child. Many students who use insulin have a small bag with a refreezable ice packet to keep the insulin cool. In addition, a sharps container for appropriate disposal of lancets and insulin needles will be needed.

Teachers of children with type 2 diabetes should encourage their physical activity and healthy foods and snacks. Physical educators who have students with type 1 diabetes must be knowledgeable about the condition and the effect of exercise on the student (Rickabaugh \& Saltarelli, 1999). Counseling may be helpful to increase compliance with daily diabetes management activities of students (Weissberg-Benchell \& Pichert, 1999).

Students who are diabetic sometimes show fatigue and confusion, have problems with reading and visual scanning, and have slower response times and difficulty attending (Thies, 1999, p. 5). Increased school absences can have adverse effects on educational progress and social development (Thies, 1999) with early onset diabetes associated with cognitive impairments (Wolters, Yu, Kail, \& Hagen, 1996). Emotional difficulties may also result from a chronic illness such as diabetes (Thies, 1999).

Recent advances in diabetes care necessitate a comprehensive education program for staff members who provide daily care to students with diabetes in schools. Implementation of a " 5 Cs of diabetes care" (cause, classification, complications, care, and cure) education training program to school personnel, described by Siminerio and Koerbel (1999), was associated with statistically significant increases in knowledge of diabetes.

\section{EPILEPSY}

Epilepsy, a chronic neurological condition, occurs when clusters of nerve cells or neurons in the brain abnormally signal. For a person to receive a medical diagnosis of epilepsy, the seizure activity must occur more than twice and be considered chronic in nature (Black \& Hynd, 1995; Coulter, 1993). During seizure activity, "neurons fire over 500 times a second whereas within normal brain activity neurons fire approximately 80 times a second." In some individuals with seizure disorders, the misfiring of neurons can occur up to hundreds of times a day (National Institute of Neurological Disorders and Stoke [NINDS], 2001, July 1, p. 2). These misfirings may result in convulsions, muscle spasms, and loss of consciousness.

Of the approximately $2,500,000$ individuals with some type of seizure disorder, $30 \%$ are children. An estimated
125,000 more individuals are diagnosed with some form of epilepsy each year (Epilepsy Foundation [EF], n.d.). Although the age of onset varies, $50 \%$ are diagnosed with epilepsy before 25 years of age and $20 \%$ before a child enters school. In $70 \%$ of the cases the etiology of the epilepsy is unknown. The remaining $30 \%$ of cases are associated with head trauma, brain tumors, poisoning, infections, and prenatal injuries. More recent research, however, suggests that epilepsy may be traced to specific gene abnormalities, which increases the probability of reoccurrence of the condition within a family (EF, n.d.).

As the classification of epilepsy types is complex (Coulter, 1993) and beyond the scope of this overview, readers are referred to Black and Hynd (1995) for a comprehensive review of epilepsy and epileptic syndromes. Seizures are classified into two major categories-partial seizures and generalized seizures-with more than 300 types of recognized seizure activity. Partial seizure may cause an individual to experience unusual feelings or sensations, ranging from joy to nausea. When having a partial seizure "the person may lose consciousness and engage in repetitive, perseverative behaviors such as blinking, mouth twitching, or walking in circles" (National Institute of Neurological Disorders and Stroke [NINDS], 2002, July 1, p. 5). Generalized seizures result from abnormal activity in many parts of the brain, which can cause "loss of consciousness, falling or massive muscle spasms." Absence seizures, tonic seizures, myoclonic seizures, and tonic-clonic seizures are different types of generalized seizures (NINDS, 2001, July 1, p. 6).

Most epilepsy cases include generalized seizure activity of various types (absence seizures, clonic seizures, tonic seizures, myoclonic seizures, atonic seizures, and tonic-clonic seizures) with family history noted as a commonality (Black \& Hynd, 1995). The most common type of epilepsy involves partial seizures, which typically begin in childhood.

Epilepsy is frequently associated with mental retardation and learning disabilities. Estimates of prevalence rates of epilepsy and mental retardation range from 5\% to $50 \%$ for individuals with cognitive dysfunction (Eriksson, Erilä, Kivimäki, \& Koivikko, 1998). The more significant the cognitive deficit, the greater is the probability for generalized seizure activity to occur (Black \& Hynd, 1995). Students who are co-morbid with mental retardation and cerebral palsy were noted to be at higher risk for unsuccessful treatment of seizure activity. Eriksson et al. noted that the more "associated" or co-conditions an individual has with epilepsy, the greater is the risk for poor seizure management and treatment (p. 470).

\section{Medical Management}

Typically, epilepsy is diagnosed and monitored using a variety of medical tests. An electroencephalogram (EEG), 
which records patterns of brainwaves, typically is administered while the individual is awake and asleep to assess the differences in brain activity during seizure activity and nonseizure activity. Other medical tests common to the assessment of epilepsy include brain scans such as computed tomography (CT), positron emission tomography (PET), and magnetic resonance imaging (MRI) scans. These brain scans assist in measuring the structure of the brain and recording the brain activity. All of these tests are conducted in conjunction with blood tests and a comprehensive medical history.

A variety of anti-epileptic drugs (AEDs) are used to treat epilepsy. These include lorazepam (Ativan), phenobarbital (Phenobarbital), clonazepam (Klonopin), and phenytoin (Dilantin) (see EF, 1998, for list of AED medications, typical adult dosages, and a partial listing of side effects). Historically, more than one AED medication often has been prescribed to treat epilepsy, and this sometimes resulted in adverse side effects such as fatigue, loss of appetite, memory problems, and attention lapses. Currently, monotherapy of AEDs (utilization of only one AED) seems to be the pharmological treatment of choice for epilepsy, as it reduces the probability of numerous side effects (Austin, Huberty, Huster, \& Dunn, 1999).

When pharmacological interventions are unsuccessful in controlling seizure activity or when the type of seizure activity is spreading within the brain, resulting in additional brain damage, surgery may be the treatment of choice. The types of surgery are as follows.

1. A lobectomy consists of removing the exact lesion or origin of the seizure activity with the intent of decreasing the misfiring of the neurons across the lobes of the brain.

2. For individuals with severe generalized seizure activity, corpus callosotomy surgery is performed to "sever the network of neural connections between the left and right hemisphere." It is performed to decrease the seizure activity and to protect the brain from continuous damage and spreading of the seizure activity throughout the brain (NINDS, 2001, July 1, p. 14).

3. A newer medical treatment for decreasing seizure activity is implantation of a vagus nerve stimulator (VNS), which was approved in 1997. This batteryoperated device is surgically placed under the skin, attached and wrapped around the vagus nerve on the lower neck. The VNS provides the brain with electrical stimulation throughout the day and is activated by the surgeon during surgery. The VNS also can be activated for more electrical impulses by placing a special magnet across the device. Because this surgery is relatively new, longitudinal data supporting effectiveness of this treatment are limited. Approximately one-third of the 10,000 individuals who have received this surgery are under 18 years of age (EF, 2002b; NINDS, 2001).

\section{School Health Care and Related Accommodations}

Many children with epilepsy require daily administration of the medication within the school day. Therefore, school personnel need training in AED administration, recording, and monitoring for potential side effects. Staff members should administer the AED medications only with water, because of the possible negative effect that fruit juices, citrus juices in particular, may produce with the medication (NINDS, 2001). Common side effects of AEDs vary by specific medication and may include irritability, difficulty concentrating, hyperactivity, clumsiness (Phenobarbital); difficulty thinking or talking, sleepiness (Topax); and rashes, gum overgrowth, hairiness, clumsiness (Dilantin) (EF, 1998).

Commonly prescribed AEDs are listed on the Epilepsy Foundation website, www.epilepsyfoundation.com, with generic names, side effects, and dosage levels. AED side effects can affect both academic performance and social adaptation within school environments (Austin et al., 1999). Although typically mild in nature, these side effects have to be recorded because they also are indicative of the potential toxicity level of the medication.

Teachers have to be aware of seizure activity the student is likely to have. Students who have absence or partial seizures in the classroom will need more frequent academic reviews because they potentially miss academic content during the seizure activity. In simple partial seizures, students may experience sensations or feelings that are not real and need reassurance from their teachers once the seizure has dissipated. In contrast, in complex partial seizures, a student may become confused during the seizure activity and remain confused after the seizure has ended. Subsequently, the teacher must ensure the student's safety until his or her confusion dissipates. Similarly, teachers need to ensure the safety of students who engage in generalized tonic-clonic (formerly referred to as grand mal) seizures because of the massive body convulsions and potential for falling (EF, 2002b).

The Epilepsy Foundation (2002b) identified the following to be indicators for contacting emergency personnel:

\footnotetext{
If a child hits his head with force, either during the seizure or just before it began, one or more of the following signs also call for immedate medical attention:

- Difficulty in rousing after twenty minutes

- Vomiting

- Complaints of difficulty with vision

- Persistent headache after a short rest period

- Unconsciousness with failure to respond
} 
- Dilation of the pupils of the eye, or if the pupils are unequal in size. (EF, 2002b, para. 2)

Although generalized tonic seizures are associated with students who have more severe cognitive disabilities, students without disabilities might also need immediate medical attention after falling with force during a seizure.

Teachers who have a student with a VNS will need specific training on how to correctly use the magnet. The magnets have to be refrigerated when not in use. Also, the magnets should not come in "contact with computer, televisions, microwave ovens or other magnets" (EF, 2002b, July 5, p. 1). Further, students with VNS should not have any type of deep-heat treatments. This type of treatment, known as diathermy, can damage the tissue and nerves attached to the stimulator (EF, 2002b).

Individual school health care plans should list types of seizures the student has, prescribed AEDs, responses for seizure activity, and documentation requirements on medication administration and seizure activity. For resources for medication documentation and observed seizure activity within the school environment, see Coulter (1993). Some students with epilepsy have physician-recommended school activity restrictions and modifications (e.g., cannot swim alone, alternative gym activities to replace gymnastics) that should be documented in the health care plan. In addition, as students approach the age at which drivers education classes are offered, school personnel should become familiar with state guidelines and restrictions related to driving for individuals diagnosed with epilepsy and include relevant information in the health care plan. The health care plan should be attached to the student's individualized educational program, reviewed frequently, and revised when data indicate this is necessary (Janz et al., 1997; Katsiyannis \& Yell, 2000).

Students with epilepsy are considered at risk; difficulties in self-esteem, lethargy, and frequent school absences are the most commonly reported school difficulties (Schouten, Oostrom, Jennekens-Schinkel, \& Peters, 2001). Students who have high-severity seizures (i.e., generalized tonicclonic seizures) are considered at higher risk for academic failure specifically in the areas of reading and math (Huberty, Austin, Huster, \& Dunn, 2000). Because these students also are frequently absent from school, additional research is needed to determine what component of the condition (i.e., the actual seizures or the associated school absences) primarily affects school performance (Black \& Hynd, 1995).

Elementary-aged students with disabilities displayed more complex seizure activity and were treated less successfully both medically and educationally (Tidman, 1999). Similarly, Austin et al. (1999) reported that children with epilepsy were observed to have academic difficulties, and male students performed more poorly than female students. More than $40 \%$ of the students had repeated at least one academic grade and had more difficulty with mathematics than sameage peers who did not have epilepsy. It seems that the longer the duration of the seizure activity (in number of years) the greater is the probability of the child's having academic difficulties. Continued research is needed to examine the potential negative effects of epilepsy and academic achievement as it relates to school absences, academic acquisition, and friendship formation within elementary and secondary grades (Coulter, 1993; Huberty et al., 2000).

Teachers of students with various health conditions should inform the student's classmates about the health conditions (Getch \& Neuharth-Prichett, 1999; RosenthalMalek \& Greenspan, 1999), but it can be done only after the student's parent or legal guardian grants permission. The Epilepsy Foundation has produced several publications suitable for use in teaching younger and older elementary students alike about epilepsy and seizures. These include Seizure Man: In the Classroom, (targeted for students 5-10 years old) and Seizure Man: First Aid for Seizures (for ages 3-8). The following videos provide introductory information regarding epilepsy, seizures, and seizure first-aid.

Understanding Seizure Disorders (available from the Epilepsy Foundation, Catalog Sales, 4351 Garden City Drive, Landover, MD, 20785)

This 11-minute video provides a basic overview of seizures, testing, and medications, and includes video clips of various types of seizures (generalized tonic clonic, simple partial, and complex partial seizures). This video is available in both English and Spanish.

\section{Seizure First Aid (Available from the Epilepsy Foundation)}

This 10-minute video includes footage of actual seizures and provides demonstrations of first-aid that should be provided to individuals who have different types of seizures (e.g., generalized tonicclonic, complex partial). It gives general guidelines on what conditions would constitute a medical emergency related to seizures. This video is available in both English and Spanish.

\section{SICKLE CELL DISEASE}

Sickle cell disease (SCD) is an inherited blood disorder affecting more than 50,000 people in the United States (McCarthy, 1993).

\footnotetext{
Sickle cell disease (commonly called sickle cell anemia) is an inherited disease in which defective, sickle-shaped red blood cells fail to carry adequate oxygen to tissues in the body. The cells also tend to block and damage the smallest blood vessels in the body, thus damaging the organs that those blood vessels serve. (Key, DeNoon, \& Boyles, 1999, p. 16)
}

Sickle cell anemia and sickle-hemoglobin C disease are common forms of sickle cell disease (Sickle Cell Disease Association of America [SCDAA], n.d.). Children who 
inherit two sickle genes (one from each parent) will have SCD, and individuals who inherit only one sickle gene will be carriers of the sickle cell trait but will not have the disorder (Georgia Comprehensive Sickle Cell Center [GCSCC] 2002a, April 6). Approximately one in every 375 AfricanAmerican children is affected with the condition (McCarthy, 1993), and individuals of Arab, Latin American, Greek, Italian, East Indian, and Caucasian ancestry also can inherit sickle cell disease (GCSCC, 2002a, April 6).

SCD causes inadequate oxygen delivery to miscellaneous organs including the brain; however, the lifespan of individuals with this condition has increased from "less than 20 years to more than 50 years of age" (Key et al., 1999, p. 16). Individuals with sickle cell disease are prone to having strokes - a loss of blood flow and oxygen that damages the brain. Of children with SCD, $10 \%$ will have a stroke before they become adults. Some children with sickle cell disease have silent strokes-strokes with no observable neurological signs but evidence of brain injury (as indicated by brain lesions identified through the use of magnetic resonance imaging (MRI) exams (Schatz, Brown, Pascual, Hsu, \& DeBaun, 2001). The overwhelming majority of these children had cognitive impairments and were more likely than children diagnosed with SCD without silent strokes to have academic difficulties. When silent strokes involve the frontal lobe, deficits in attention and executive functions often are observed.

When the sickle cells block blood flow and break apart, a variety of medical complications can arise. These complications include episodes of pain (sometimes called "pain crises"), strokes, bone damage, leg ulcers, infections, and gallstones, as well as blockages in the lungs, spleen, and liver. Other complications are anemia (low red blood count), eye and kidney damage, jaundice, priapism (painful erections of long duration), and delayed growth. Individuals with SCD also may have delayed puberty and be of short stature (GCSCC, 2002a, April 6). The primary cause of death of individuals with sickle cell disease is acute chest syndrome (ACS), which can stem from infections and other causes (Vichinsky et al., 2000).

\section{Medical Management}

McCarthy (1993) recommended the need for "comprehensive health-care services, education about the disease and its complications, and genetic counseling" (p. 1209). Also, infants diagnosed with the condition should be given oral prophylactic penicillin (or another antibiotic) twice a day. This medication has been shown to reduce bacterial infections that lead to recurring illness and death of children with sickle cell disease. Prophylactic penicillin should be given until children are at least 5 to 6 years of age (GCSCC, 2002a, April 6).
Blood transfusions, which may be given every 3 to 6 weeks, have been documented to reduce stroke risk. These transfusions, however, carry risks including possible infections, allergic reactions, and iron overload, which occurs from excessive iron build-up (Key et al., 1999). Some people with SCD who present with acute chest syndrome can be treated successfully with a combination of blood transfusions, oxygen therapy, pain medications (e.g., antibiotics, bronchodilators, and increased fluids, both oral and intravenous) (Vichinsky et al., 2000). The neurological and neurodevelopmental status of children with sickle cell anemia should be monitored across time and should include examinations to identify strokes (Chua-Lim, Moore, McCleary, Shah, \& Mankad, 1993).

\section{School Health Care and Related Accommodations}

"Those with sickle cell should be treated as normal as possible, with an awareness that they may have intermittent episodes of pain, infection, or fatigue" (GCSCC, 2002b, February 1, p. 1). Teachers should assist students with sickle cell disease to avoid very hot or cold temperatures and overexertion, as well as encouraging them to drink an appropriate amount of fluids to prevent pain episodes. Further, teachers should allow the child to take extra breaks to obtain water or allow the child to keep a filled water bottle at his or her desk. Additional bathroom breaks will have to be provided because of the increased fluid intake and because the kidneys of individuals with SCD have difficulty retaining water. Teachers also should provide breaks to the student when he or she is tired or is having an episode, and should monitor the student to prevent overexertion (GCSCC, 2002b, February 1). Pain medications may have to be administered at school for episodes of pain that can be managed within the school setting.

Teachers should become familiar with, and encourage students to use, various coping strategies during pain episodes. Gil et al. (2001) reported that children and youth with SCD who were trained to use coping skills (relaxation with deep breathing, calming self-talk, and pleasant imagery) to deal with pain episodes were more likely to take an active approach to pain management than were children with SCD who did not receive this training. Those authors indicated that on days that children with SCD had increased pain, they were more likely to take medication, have health care contacts, reduce their activity level, and practice their coping skills. Children who practiced their coping skills on higher-pain days were more likely to maintain their typical activity level at home and school and less likely to have a major medical care contact (i.e., hospital admission, clinic or emergency room visit). The authors recommended more comprehensive skills training for children with SCD to include the coping skills strategies as well as "behavioral 
strategies such as activity pacing or scheduling pleasant activities during pain episodes" (p. 171).

Warning signs that may indicate that a child with SCD may need to immediately see his or her physician or go to the emergency room include fever of $101^{\circ} \mathrm{F}$. or above, sudden change in vision, weakness or loss of feeling, shortness of breath, swelling in the hands, joints, or feet, as well as pain in the head, chest, joints, or penis (GCSCC, 2002a, February 1; Sickle Cell Advisory Committee [SCAC], 1999, September). Vichinsky et al. (2000) documented that children with SCD who were 9 years of age and younger and diagnosed with ACS had initial symptoms including fever, wheezing, and coughing. Teachers should watch for these warning signs and take a child's temperature as needed if a fever is suspected. Warning signs that an individual student is most likely to display must be determined from the child's parents and written into the student's health care plan, along with specific urgent care responses that the school staff should heed immediately when indicated.

Preschool children with sickle cell anemia, compared to children without the condition, were more frequently noted to have deficits in school-readiness skills (Chua-Lim et al., 1993). In addition, students with sickle cell disease may have more absences because of severe pain crises that may require them to stay home, and at times, be hospitalized. Consequently, school personnel will have to arrange for the child to make up the work missed during any absence (GCSCC, 2002b, February 1).

\section{SUMMARY AND RECOMMENDATIONS}

Because of the overwhelming increase of students identified in the category of Other Health Impairment, educators must be more responsive to the needs of students diagnosed with a wide range of chronic health conditions. Etscheidt and Barlett (1999) recommend that educational teams take a four-step approach when determining related services and health care needs for children with other health impairments:

1. Review the child's IEP.

2. Discuss the need for supplemental aids and services.

3. Document the decision-making process and product.

4. Determine the data-collection procedures for using these supplemental aids and services.

Schools utilizing this approach should have the necessary documentation and data to assist them in providing appropriate educational services for all the students in their districts.

The need for a comprehensive preservice education program focusing on health care services is essential. In part, the ability to plan for and respond appropriately to the student's educational needs and health needs is contingent on the training received at the preservice level for future special and general educators. State Departments of Education must reexamine teacher-certification requirements to assure that those leaving teacher-preparation programs acquire the knowledge and skills necessary to teach students with physical and health disabilities (Heller et al., 1999).

Furthermore, comprehensive, updated inservice training for school personnel, including practicing teachers and nurses, has to occur to enable students with health conditions to receive an appropriate and safe education in their least restrictive environment. AAP (1990a) called for increased education of school personnel about chronic health conditions and related health care management in part to combat anxiety and fears that teachers may have regarding such conditions. All staff members involved in implementing school health procedures should be given child-specific initial training as well as follow-up training (Heller et al., 1997).

The advent of the Internet has made available a seemingly endless supply of valuable information on chronic health conditions of children, for use by parents, teachers, school nurses, and other school personnel. With this newer and ever-changing means of obtaining information, however, comes the caveat, "Consumers beware." When accessing Internet sources to obtain information, readers must carefully assess the credibility of organizations and authors of websites from which they seek and obtain information. Too, web addresses and uniform resource locators (URLs) change frequently. On occasion, an individual or organization with no connection to the original website utilizes the original web address of an organization or individual. Each of the web site addresses for all text content from the electronic Internet sources included within this article were current immediately prior to publication.

\section{ADDITIONAL SOURCES OF INFORMATION}

American Diabetes Association

1701 North Beauregard Street

Alexandria, VA 22311

1-800-DIABETES (342-2383) or

1-800-232-3472

http://www.diabetes.org

American Lung Association

1740 Broadway

New York, NY 10019

(212) 315-8700

http://www.lungusa.org 
Cystic Fibrosis Foundation

6931 Arlington Road

Bethesda, MD 20814

(301) 951-4422

1-800-FIGHT CF (344-4823)

http://www.cff.org

Elizabeth Glaser Pediatric AIDS Foundation

2950 31st Street \#125

Santa Monica, CA 90405

1-888-499-HOPE (4673)

http://www.pedaids.org

Epilepsy Foundation

4351 Garden City Drive

Landover, MD 20785-7223

1-800-332-1000

http://www.epilepsyfoundation.org

1-800-213-5821 (publication ordering only)

Food Allergy \& Anaphylaxis Network

10400 Eaton Place, Suite 107

Fairfax, VA 22030-2208

1-800-929-4040

http://www.foodallergy.org

National Pediatric \& Family HIV Resource Center (NPHRC) University of Medicine \& Dentistry of New Jersey

30 Bergen Street-ADMC \#4

Newark, NJ 07103

(973) 972-0410

1-800-362-0071

http://www.pedhivaids.org

Sickle Cell Information Center

Georgia Comprehensive Sickle Cell Center

PO Box 109

Grady Memorial Hospital

80 Jessie Hill Jr. Drive SE

Atlanta, GA 30303

(404) 616-3572

http://www.scinfo.org

United States Department of Health and Human Services

National Institutes of Health:

- National Institute of Allergy and Infectious Diseases

(NIAID) http://www.niaid.nih.gov/default.htm

- National Institute of Diabetes and Digestive and Kidney

Diseases (NIDDK) http://www.niddk.nih.gov/

- National Heart, Lung, and Blood Institute (NHLBI) http://www.nih.gov/icd/

- National Institute of Neurological Disorders and Stroke (NINDS) http://www.ninds.nih.gov/

\section{REFERENCES}

Almqvist, C., Larsson, P. H., Egmar, A. C., Hedren, M., Malmberg, P., \& Wickman, M. (1999). School as a risk environment for children allergic to cats and a site for transfer of cat allergen to homes. Journal of Allergy and Clinical Immunology, 103(2), 1012-1017.

American Academy of Pediatrics, Committee on Pediatric AIDS. (1998). Human immunodeficiency virus/acquired immunodeficiency syndrome education in schools. Pediatrics, 101(5), 933-935.

American Academy of Pediatrics, Committee on Children with Disabilities and Committee on School Health. (1990a). Children with health impairments in schools. Pediatrics, 86, 636-638.

American Academy of Pediatrics, Committee on School Health. (1990b). Guidelines for urgent care in schools. Pediatrics, 86(6), 999-1000.

American Academy of Pediatrics, Task Force on Pediatric AIDS. (1988). Pediatric guidelines for infection control of human immunodeficiency virus (acquired immunodeficiency virus in hospitals, medical offices, schools, and other settings). Pediatrics, 82, 801-807.

American Diabetes Association. (2001). Care of children with diabetes in the school and day care setting. Diabetes Care, 24, S108-S112.

American Diabetes Association. (2002). New diabetes products. Diabetes Forecast, 55(1), 1-4. Retrieved on February 11, 2002, from http:// www.diabetes.org/main/community/forecast/jan_2002_new_diabetes_ products.jsp

American Diabetes Association. (n.d, a). Complications. Retrieved on February 11,2002 , from http://www.diabetes.org/maintype $2 /$ complications/ complications.jsp

American Diabetes Association. (n.d, b). Hyperglycemia. Retrieved on July 1, 2002, from http://www.diabetes.org/main/application/commercewf? orgin $=*$.jsp\&event $=\operatorname{link}\left(\mathrm{C} 4 \_6\right)$

American Diabetes Association. (n.d, c). Hypoglycemia. Retrieved on July 1, 2002, from http://www.diabetes.org/main/application/commercewf? orgin $=*$.jsp\&event $=\operatorname{link}\left(\mathrm{C} 4 \_5\right)$

American Lung Association. (2002a). Asthma attacks. Retrieved on June 10, 2002, from http://www.lungusa.org/asthma/astasthmatk.html

American Lung Association. (2002b). Peak flow chart. Retrieved on June 10, 2002, from http://www.lungusa.org/asthma/astpeakchrt.html

Aronson, S. S. (1995). Meeting the health needs of children with asthma. Child Care Information Exchange, 101, 59-60.

Asthma and Allergy Foundation of America. (2002). "Answers" fact sheets: Food allergies. Retrieved July 10, 2002, from http://www.aafa.org/ templ/display.cfm? $\mathrm{id}=193 \& \mathrm{sub}=223$

Austin, J. K., Huberty, T. J., Huster, G. A., \& Dunn, D. W. (1999). Does academic achievement in children with epilepsy change over time? Developmental Medicine and Child Neurology, 41(7), 473-479.

Ballard, D. J., White, D. M., \& Glascoff, M. A. (1990). AIDS/HIV education for preservice elementary teachers. Journal of School Health, $60(6), 262-265$.

Beverly, C. L. (1995). Providing a safe environment for children infected with the human immunodeficiency virus. Topics in Early Childhood Special Education, 15(1), 100-109.

Black, K. C., \& Hynd, G. W. (1995). Epilepsy in the school aged child: Cognitive-behavioral characteristics and effects on academic performance. School Psychology Quarterly, 10(4), 345-358.

Brown, L. K., Lourie, K. J., \& Pao, M. (2000). Children and adolescents living with HIV and AIDS: A review. Journal of Child Psychiatry and Allied Disciplines, 41(1), 81-96.

Caldwell, T. H., \& Sirvis, B. (1991). Students with special health care conditions-An emerging population presents new challenges. Preventing School Failure, 35(3), 13-18.

Celano, M. P., \& Geller, R. J. (1993). Learning, school performance, and children with asthma: How much at risk? Journal of Learning Disabilities, 26(1), 23-32. 
Chua-Lim, C., Moore, R. B., McCleary, G., Shah, A., \& Mankad, V. N. (1993). Deficiencies in school readiness skills of children with sickle cell anemia: A preliminary report. Southern Medical Journal, 86(4), $397-402$

Coulter, D. L. (1993). Epilepsy and mental retardation: An overview. American Journal on Mental Retardation, 98, 1-11.

Council for Exceptional Children. (2000). What every special educator should know-The standards for the preparation and licensure of special educators (4th ed.). Reston, VA: CEC.

Coutts, C. (2000). Food reactions: Allergic or intolerant? Parenting, 14(9), 240.

Cross, G., \& Jones, M. J. (1996). Addressing medical and emergency procedures in inclusive settings. In D. L. Ryndak, \& S. Alper (Eds.), Curriculum content for students with moderate and severe disabilities in inclusive settings (pp. 269-288). Boston: Allyn \& Bacon.

Cystic Fibrosis Foundation. (1997a, March). Caring for your nebulizerWhat you should know. Homeline, pp. 4-6. Retrieved on May 16 , 2002, from http://www.cff.org/home\%20line/homeline199703.htm

Cystic Fibrosis Foundation. (1997b). Consumer fact sheet-An introduction to chest physical therapy. Bethesda, MD: CFF.

Cystic Fibrosis Foundation. (1999, December). Lung transplantation. Bethesda, MD: CFF

Cystic Fibrosis Foundation. (2001a, December). Facts about cystic fibrosis. Bethesda, MD: CFF

Cystic Fibrosis Foundation. (2001b, December). Gene therapy and cystic fibrosis. Bethesda, MD: CFF.

Cystic Fibrosis Foundation. (2001c, December). Progress in CF research. Bethesda, MD: CFF

Cystic Fibrosis Foundation. (2002, March 8). Facts about cystic fibrosis. Retrieved on May 16, 2002, from http://www.cff.org/facts.htm

da Costa, I. G., Rapoff, M. A., Lemanek, K., \& Goldstein, G. L. (1997). Improving adherence to medication regimen for children with asthma and its effect on clinical outcome. Journal of Applied Behavior Analysis, 30(4), 687-691.

Dibs, S. D., \& Baker, M. D. (1997). Anaphylaxis in children: A 5-year experience. Pediatrics, 99(1), e 7. Retrieved on May 23, 2002, from http://www.pediatrics.org/cgi/content/full/99/1/e7

Diette, G. B., Markson, L., Skinner, E. A., Nguyen, T. T. H., AlgattBergstrom, P., \& Wu, A. W. (2000). Nocturnal asthma in children affects school attendance, school performance, and parents' work attendance. Archives of Pediatric and Adolescent Medicine, 154, 923-928.

Environmental Protection Agency. (2001, November 27). IAQ tools for schools: Managing asthma in the school environment-The asthma epidemic. Retrieved on January 24, 2002, from http://www.epa.gov/ iaq/schools/asthma/asthma_epidemic.htm

Epilepsy Foundation. (1998). Medicines for epilepsy. [Brochure]. Landover, MD: Author.

Epilepsy Foundation. (2002a). Answerplace-Vagus nerve stimulation. Retrieved on July 5, 2002, from http://www.efa.org/answerplace/vns

Epilepsy Foundation. (2002b). Making our schools seizure smart. Retrieved on July 5, 2002, from http://www.efa.org/answerplace/teach $\mathrm{ers} / \mathrm{html}$

Epilepsy Foundation. (n.d.). Information and education. Retrieved on December 8, 1998, from http://www.efa.org/education/facts.html

Eriksson, K., Erilä, T., Kivimäki, T., \& Koivikko, M. (1998). Evolution of epilepsy in children with mental retardation: Five-year experience in 78 cases. American Journal on Mental Retardation, 102(5), 464-472.

Etscheidt, S. K., \& Bartlett, L. (1999). The IDEA amendments: A four-step approach for determining supplementary aids and services. Exceptional Children, 65(2), 163-174.

Federal Interagency Forum on Child and Family Statistics. (2001). America's children: Key national indicators of well-being, 2001. Federal
Interagency Forum on Child and Family Statistics, Washington, DC. Retrieved May 20, 2002, from http://childstats.gov

FitzSimmons, S. C. (1993). The changing epidemiology of cystic fibrosis. Journal of Pediatrics, 122(1), 1-9.

Food Allergy and Anaphylaxis Network. (2002, January 2). Information about anaphylaxis. Retrieved July 10, 2002, from http://www.food allergy.org/anaphylaxis.html

Food Allergy Initiative. (n.d.). Living with food allergies. Retrieved July 11, 2002, from http://foodallergyinitiative.org

Formanek, R. (2001). When food becomes the enemy. FDA Consumer, 35, $10-16$.

Gandy, L. T., Yadrick, M. K., Boudreaux, L. J., \& Smith, E. R. (1991). Serving children with special heath care needs: Nutrition services and employee training needs in the school lunch program. Journal of the American Dietetic Association, 91(12), 1585-1586.

Georgia Comprehensive Sickle Cell Center (2002a, April 6). Sickle cell anemia. Retrieved on April 15, 2002, from http://www.scinfo.org/ sicklept.htm

Georgia Comprehensive Sickle Cell Center (2002b, February 1). Sickle cell information for teachers, students, and employers. Retrieved on April 15, 2002, from http://www.scinfo.org/teacher.htm

Getch, Y. Q., \& Neuharth-Pritchett, S. (1999). Children with asthma: Strategies for educators. Teaching Exceptional Children, 31(3), 30-36.

Giardina, R. G., \& Psota, C. E. (1997). Universal precautions and infection control in a school setting. In S. Porter, M. Haynie, T. Bierle, T. H. Caldwell, \& J. S. Palfrey (Eds.), Children and youth assisted by medical technology in educational settings-Guidelines for care (2nd ed.) (pp. 74-78). Baltimore: Paul H. Brookes.

Gil, K. M., Anthony, K. K., Carson, J. W., Redding-Lallinger, R., Daeschner, C. W., \& Ware, R. E. (2001). Daily coping practice predicts treatment effects in children with sickle cell disease. Journal of Pediatric Psychology, 26(3), 163-173.

Grubman, S., Gross, E., Lerner-Weiss, N., Hernandez, M., McSherry, G. D., Hoyt, L. G., et al. (1995). Older children and adolescents living with perinatally acquired human immunodeficiency virus infection. Pediatrics, 95(5), 657-663.

Hale, A. R. (1997). Human immunodeficiency virus and acquired immunodeficiency syndrome. In S. Porter, M. Haynie, T. Bierle, T. H. Caldwell, \& J. S. Palfrey (Eds.), Children and youth assisted by medical technology in educational settings-Guidelines for care ( $2 \mathrm{~d}$ ed.) (pp. 83-93). Baltimore: Paul H. Brookes.

Hansen, J. R., Fulop, M. J., \& Hunter, M. K. (2000). Type 2 diabetes mellitus in youth: A growing challenge. Clinical Diabetes, 18(2), 52-56.

Hartocollis, A. (1998, September 23). Nothing's safe: Some schools ban peanut butter as allergy threat. New York Times, 148(51289) pp. A1, B11.

Hay, G. H., Harper, T. B. III, \& Courson, F. H. (1994). Preparing school personnel to assist students with life-threatening food allergies. Journal of School Health, 64(3), 119-121.

Heller, K. W. (1997). The critical need for physical/health disability certification. Physical Disabilities: Education and Related Services, 16(1), $1-5$.

Heller, K. W., Fredrick, L. D., Dykes, M. K., Best, S., \& Cohen, E. T. (1999). A national perspective of competencies for teachers of individuals with physical and health disabilities. Exceptional Children, 65(2), 219-234.

Heller, K. W., Fredrick, L., \& Rithmire, N. M. (1997). Special health care procedures in the schools. Physical Disabilities: Education and Related Services, 15(2), 5-22.

Heller, K. W., Wolff, L., Forney, P., Alberto, P., Schwartzman, M., \& Goeckel, T. (2000). Medications and procedures for administration. In K. W. Heller, P. E. Forney, P. A. Alberto, M. N. Schwartzman, \& T. M. 
Goeckel, Meeting physical and health needs of children with disabilities (pp. 67-96). Belmont, CA: Wadsworth/Thomson Learning.

Henley, L. D., \& Hill, I. D. (1990). Errors, gaps, and misconceptions in the disease-related knowledge of cystic fibrosis patients and their families. Pediatrics, 85, 1008-1014.

Huberty, T. J., Austin, J. K., Huster, G. A., \& Dunn, D. W. (2000). Relations of change in condition severity and school self-concept to change in achievement-related behavior in children with asthma or epilepsy. Journal of School Psychology, 38(3), 259-276.

Individuals with Disabilities Education Act-Final Regulations (1999). 34 CFR $\S 300.7$ (b) (9).

Individuals with Disabilities Education Act-Final Regulations (1999). 34 C.F.R. $\$ 300.24$ (b) (12).

Janz, J., Beyer, H., Schwab, N., Anderson, B., Caldwell, T., \& Harrison, J. (1997). Legal issues in the education of students with special health care needs. In S. Porter, M. Haynie, T. Bierle, T. Calwell, \& J. Palfrey (Eds), Children and youth assisted by medical technology in educational settings-Guidelines for care (2nd ed.). (pp. 19-39). Baltimore: Paul H. Brookes.

Johnson, M. P., Lubker, B. B., \& Fowler, M. G. (1988). Teacher needs assessment for the educational management of children with chronic illnesses. Journal of School Health, 58(6), 232-235.

Katsiyannis, A., \& Yell, M. (2000). The Supreme Court and school health services: Cedar Rapids v. Garret F. Exceptional Children, 66(3), 317-326.

Kelker, K., Hecimovic, A., \& LeRoy, C. H. (1994). Designing a classroom and school environment for students with AIDS: A checklist for teachers. Teaching Exceptional Children, 26(4), 52-55.

Key, S. W., DeNoon, D. J., \& Boyles, S. (1999). Sickle cell effects on brain found in very young children. World Disease Weekly Plus, 16-17.

Lavin, A. T., Porter, S. M., Shaw, D. M., Weill, K. S., Crocker, A. C., \& Palfrey, J. S. (1994). School health services in the age of AIDS. Journal of School Health, 64(1), 27-31.

Levetan, C. (2001). Into the mouths of babes: The diabetes epidemic in children. Clinical Diabetes, 19(3), 102-104.

Luder, D. (1997). Exercise-The facts. Homeline, 1-4. Retrieved on May 16, 2002, from http://www.cff.org/home\%20line/homeline199703.htm

The Lung Association (2002, July 19). Asthma. Retrieved on June 10, 2002, from http://www.lung.ca/asthma/asthma1.html

The Lung Association (n.d.). Asthma management. Retrieved on June 10, 2002, from http://www.lung.ca/asthma/manage/action.html

Mayo Clinic. (2002, May 14). What is cystic fibrosis? Retrieved on May 16, 2002, from http://www.mayoclinic.com

McCarthy, M. (1993). USA recommends universal sickle-cell screening. Lancet, 341(8854), 1209.

Meeropol, E. (1997). Alert: Latex allergy. In S. Porter, M. Haynie, T. Bierle, T. H. Caldwell, \& J. S. Palfrey (Eds.), Children and youth assisted by medical technology in educational settings-Guidelines for care (2d ed.) (pp. 79-82). Baltimore: Paul H. Brookes.

National Diabetes Education Program, National Institute of Diabetes \& Digestive \& Kidney Diseases, National Institutes of Health (2002, February). Diabetes in children and adolescents. Retrieved on May 16, 2002, from http://ndep.nih.gov/get-info/childrensfacts.htm

National Heart, Lung, and Blood Institute, National Institutes of Health. (n.d.). Controlling your asthma. Retrieved on May 16, 2002, from http://www.nhlbi.nih.gov/health/public/lung/asthma/asth_fs.pdf

National Institute of Allergy and Infectious Diseases, National Institutes of Health. (2001a, May). HIV infection and AIDS: An overview. Retrieved on May 16, 2002, from http://www.niaid.nih.gov/factsheets/hivinf.htm

National Institute of Allergy and Infectious Diseases, National Institutes of Health. (2001b, October). HIV infection in adolescents. Retrieved on May 16, 2002, from http://www.niaid.nih.gov/factsheets/hivadoles cent.htm
National Institute of Allergy and Infectious Diseases, National Institutes of Health. (2001, June 25). Fact sheet-Food allergy and intolerances. Retrieved on May 16, 2002, from http://www.niaid.nih.gov/factsheets/ food.htm

National Institute of Allergy and Infectious Diseases, National Institutes of Health. (n.d.). Backgrounder-HIV infection in infants and children. Retrieved on May 16, 2002, from http://www.niaid.nih.gov/news room/simple/background.htm

National Institute of Diabetes \& Digestive \& Kidney Diseases, National Institutes of Health. (1998, February 12).Cystic fibrosis-Research directions. Bethesda, MD: Retrieved on May 16, 2002, from http:www.niddk.nih.gov/health/endo/endo/pubs/cystic/cystic.htm

National Institute of Diabetes \& Digestive \& Kidney Diseases, National Institutes of Health (2000a, February). Devices for taking insulin. Bethesda, MD: Retrieved on May 16, 2002 from http://www.niddk. nih.gov/health/diabetes/summary/altins.altins.htm

National Institute of Diabetes \& Digestive \& Kidney Diseases, National Institutes of Health (2000b, April). Diabetes diagnosis. Bethesda, MD: Retrieved on May 16, 2002, from http://www.niddk.nih.gov/health/ diabetes/pubs/diagnosis/diagnosis.htm

National Institute of Diabetes \& Digestive \& Kidney Diseases, National Institutes of Health (2000c, August). Prevent diabetes problemsKeep your diabetes under control. Bethesda, MD: Retrieved on May 16, 2002, from http://www.niddk.nih.gov/health/diabetes/pubs/ complications/control/control.htm

National Institute of Diabetes \& Digestive \& Kidney Diseases, National Institutes of Health (n.d.). Medicines for people with diabetesSpecific medicines. Retrieved on May 16, 2002, from http://www. niddk.nih.gov/health/diabetes/pubs/med/specific.htm

National Institute of Neurological Disorders and Stroke, National Institutes of Health (2001, July 1). Seizures and epilepsy: Hope through research. Retrieved on May 16, 2002, from http://www.ninds.nih.gov/ health and medical/pubs/seizures_and_epilepsy

Nowak-Wegrzyn, A., Conover-Walker, M. K., \& Wood, R. A. (2001). Food-allergic reactions in schools and preschools. Archives of Pediatrics and Adolescent Medicine, 155(7), 790-795.

Porter, S., Haynie, M., Bierle, T., Caldwell, T. H., \& Palfrey, J. S. (1997). Children and youth assisted by medical technology in educational settings: Guidelines for care (2nd ed.). Baltimore: Paul H. Brookes.

Preboth, M. (2000). Diabetes in the school and day care setting. American Family Physician, 62(5), 1189.

Raj, A., Mishra, A., Feinsilver, S. H., \& Fein, A. M. (2000). An estimate of the prevalence and impact of asthma and related symptoms in a New York City middle school [Abstract]. Chest, 118(4), 84S.

Rana, U. A., Jurgens, S. M., Mangione, S., Elia, J., \& Tollerud, D. J. (2000). Asthma prevalence among high absentees of two Philadelphia middle schools [Abstract]. Chest, 118(4), 79S.

Rapport, M. J. K. (1996). Legal guidelines for the delivery of special health care services in schools. Exceptional Children, 62(6), 537-549.

Reid, R. (1999). Attention deficit hyperactivity disorder: Effective methods for the classroom. Focus on Exceptional Children, 32(4), 1-20.

Rickabaugh, T. E., \& Saltarelli, W. (1999). Knowledge and attitudes related to diabetes and exercise guidelines among selected diabetic children, their parents, and physical education teachers. Research Quarterly for Exercise and Sport, 70(4), 389-394.

Rosenbloom, A. (2001). Not "adults-only" anymore. Diabetes Forecast, 54(3), 82 .

Rosenthal-Malek, A., \& Greenspan, J. (1999). A student with diabetes is in my class. Teaching Exceptional Children, 31(3), 38-43.

Schatz, J., Brown, R. T., Pascual, J. M., Hsu, L., \& DeBaun, M. R. (2001). Poor school and cognitive functioning with silent cerebral infarcts and sickle cell disease. Neurology, 56, 1109-1111. 
Page 23 of this issue is an advertisement. 
Schwartz, W. (1999). Supporting students with asthma. ERIC/CUE Digest, 151. (ERIC Document Reproduction Service No. ED438339)

Schouten, A., Oostrom, K., Jennekens-Schinkel, A., \& Peters, A. C. B. (2001). School career of children is a risk before diagnosis of epilepsy only. Developmental Medicine and Child Neurology, 43(8), 575-576.

Sickle Cell Advisory Committee. (1999, September). Sickle cell disease: Information for school personnel. Trenton, NJ: Special Child, Adult and Early Intervention Services, New Jersey Department of Health and Senior Services. Retrieved on June 23, 2002, from http://www.state.nj. us/health/fhs/sicklecell/index.org/whatistext2.htm

Sickle Cell Disease Association of America, Inc. (n.d.). What is sickle cell disease? Retrieved on June 15, 2002, from http://www.sicklecell disease.org/whatistext 2 .htm

Simeonsson, N., Lorimer, M., Shelley, B., \& Sturtz, J. (1995). Asthma: New information for the early interventionist. Topics in Early Childhood Special Education, 15(1), 32-43.

Siminerio, L., \& Koerbel, G. (1999). Evaluating the effectiveness of a diabetes education program for school personnel [Abstract]. Diabetes, 49(5), A158-A159.

Simpson, R. L., Whelan, R. J., \& Zabel, R. H. (1993). Special education personnel preparation in the 21 st century: Issues and strategies. Remedial \& Special Education, 14(2), 7-22.

Task Force on Pediatric AIDS. (1991). Education of children with human immunodeficiency virus infection. Pediatrics, 88(3), 645-648.

Taylor, S. L., \& Hefle, S. L. (2001). Food allergies and other food sensitivities. Food Technology, 55(9), 68-83.

Thies, K. M. (1999). Identifying the educational implications of chronic illness in children. Journal of School Health, 69(10), 392-397.

Thompson, R. J., Gustafson, K. E, Meghdadpour, S., Harell, E. S, Johndrow, D. A., \& Spock, A. (1992). The role of biomedical and psychosocial processes in the intellectual and academic functioning of children and adolescents with cystic fibrosis. Journal of Clinical Psychology, 48(1), 3-10.

Tidman, L. (1999). Epilepsy in children attending primary school. Archives of Disease in Childhood, 80, G127.

Touchette, N. (2000). Kids and type 2. Diabetes Forecast, 53(11), 79-84.
Tyler, J. T., \& Colson, S. (1994). Common pediatric disabilities: Medical aspects and educational implications. Focus on Exceptional Children, 27(4), 1-16.

U.S. Department of Education. (2001). Twenty-third annual report to Congress on implementation of the Individuals with Disabilities Education Act. Washington, DC: Author. Retrieved on July 8, 2002, from http://www.ed.gov/offices/OSERS/OSEP/Products/OSEP2001AnlRpt/ index.html

Vargas, I., Schachner, H. C., Solowiejczyk, J., Almeida, K. L., Leibel, R. L., \& Goland, R. S. (1999). Clinical characteristics in an ethnically diverse group of children with type 2 diabetes [Abstract]. Diabetes, 48(5), A84.

Vichinsky, E. P., Neumayr, L. D., Earles, A. N., Williams, R., Lennette, E. T., Dean, D., et al. (2000). Causes and outcomes of the acute chest syndrome in sickle cell disease. New England Journal of Medicine, 342(5), 1855-1865.

Weissberg-Benchell, J., \& Pichert, J. (1999). Counseling techniques for clinicians and educators. Diabetes Spectrum, 12(1), 103-107.

Williams, J. K., \& McCarthy, A. M. (1995). School nurses' experience with children with chronic conditions. Journal of School Health, 65(6), 234-236.

Williams-Warren, J. (1998). Caring for and cleaning your nebulizer and compressor. Homeline, 1-7. Retrieved on May 16, 2002, from http://www.cff.org/home\%20line/homeline199802.htm

Wolters, C. A., Yu, S. L., Kail, R., \& Hagen, J. W. (1996). Short-term memory and strategy use in children with insulin-dependent diabetes mellitus. Journal of Consulting and Clinical Psychology, 64(6), 1397-1405.

Yell, M. (1998). The law and special education. Upper Saddle River, NJ: Merrill, Prentice Hall.

Yell, M. L., \& Shriner, J. G. (1997). The IDEA Amendments of 1997: Implications for special and general education teachers, administrators, and teacher trainers. Focus on Exceptional Children, 30(1), 1-19.

Yousef, J. M. S. (1995). Insulin-dependent diabetes mellitus: Educational implications. Physical Disabilities: Education and Related Services, 13(2), 43-53. 